Studies in African Linguistics

Volume 35, Number 1, 2006

\title{
ASPECTS OF MAAY PHONOLOGY AND MORPHOLOGY*
}

\author{
Mary Paster \\ Pomona College
}

This paper presents a descriptive overview of the phonology and morphology of the Lower Jubba dialect of Maay, a language of southern Somalia. The paper highlights several points of typological, dialectological, and theoretical interest in this language. For example, the nominal morphology exhibits a somewhat unusual pattern of plural marking that interacts in a complex way with the gender marking system. Where relevant, comparisons are made between this dialect and other dialects of Maay and Somali, and speculation is made as to the historical origin of some of the unusual phonological and morphological phenomena observed in this dialect.

\section{Introduction.}

This paper presents aspects of the phonology and morphology of a dialect of Maay, a Cushitic language of southern Somalia. The dialect to be discussed here, which I will refer to as Lower Jubba Maay (LJM), appears to be undescribed in the literature. The data in this paper are the result of four months of research with a native speaker of LJM in Pittsburgh, Pennsylvania in winter and spring of 2006.

1.1 Somali Dialects. There exists no comprehensive study of Somali and Maay dialects, and in fact the question of whether Somali and Maay represent dialects of the same language or different languages entirely has not been resolved, since

\footnotetext{
* Many thanks to the Maay consultant for this research, Mr. Osman Mohamed. Thanks also to Dave Odden and an anonymous reviewer for helpful comments on an earlier version of this paper, and to the students in Linguistics 1441/2441 at University of Pittsburgh, who ran some of the elicitation sessions from which data presented here have been taken. All data are from my own field notes.
} 
what are sometimes described as Somali dialects (including Maay dialects) are in some cases mutually unintelligible (Saeed 1987: 2). Anecdotal impressions from Maay speakers suggest that the language situation in Somalia is a "dialect continuum" in that neighboring dialects are all mutually intelligible, but the dialects at opposite ends of the continuum are not mutually intelligible. For example, the Maay consultant for the present study is from the far south of Somalia and reports that he is able to understand the Central Somali dialect described by Saeed (1982) but not the Somali spoken in the far north. As will be discussed, in several ways LJM appears to be an innovative dialect with respect to other dialects of Maay and Somali, such as Central Somali (Saeed 1982) and Standard Somali (Saeed 1987).

Map 1: Map of Somalia showing Lower Jubba state and city of Kowan

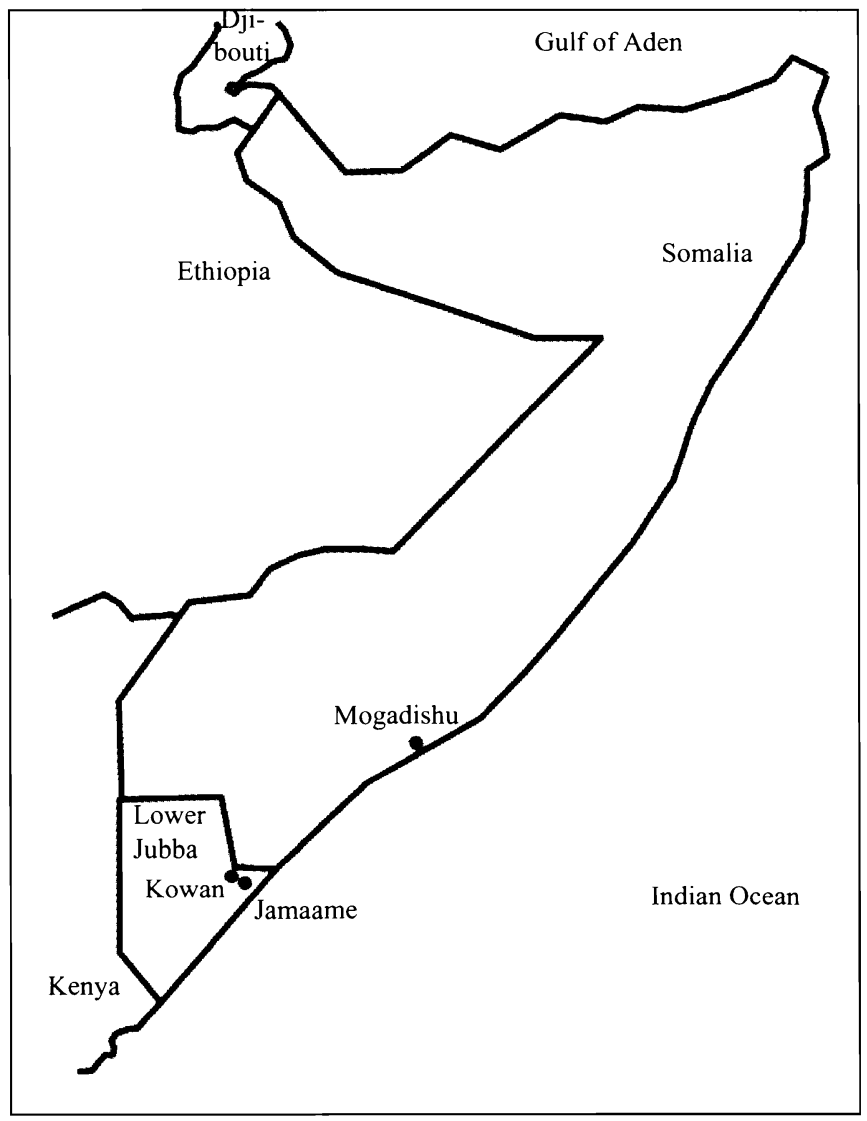


1.2 Lower Jubba Maay. The dialect to be described here (Lower Jubba Maay, or LJM) is spoken in the state of Lower Jubba, which is the southernmost state in Somalia. The consultant is a 27 year-old man from Kowan, which is just across the Jubba River from the city of Jamaame (see Map 1).

LJM shares many features with Central Somali (Saeed 1982) and the Standard Somali spoken in the north, but there are significant differences, including differences in the consonant and vowel inventories, morphology, and lexical items. These will be pointed out throughout the paper as they become relevant.

\section{Phonology.}

2.1 Segmental Inventory. The segmental inventory of LJM differs not only from the inventory of Standard Somali, but also from that of the more closely related Central Somali. The consonantal inventory of LJM is presented below. Sounds in parentheses are very rarely attested, while sounds in brackets occur in surface forms but are not posited as phonemes of the language.

(1) Consonants of Lower Jubba Maay

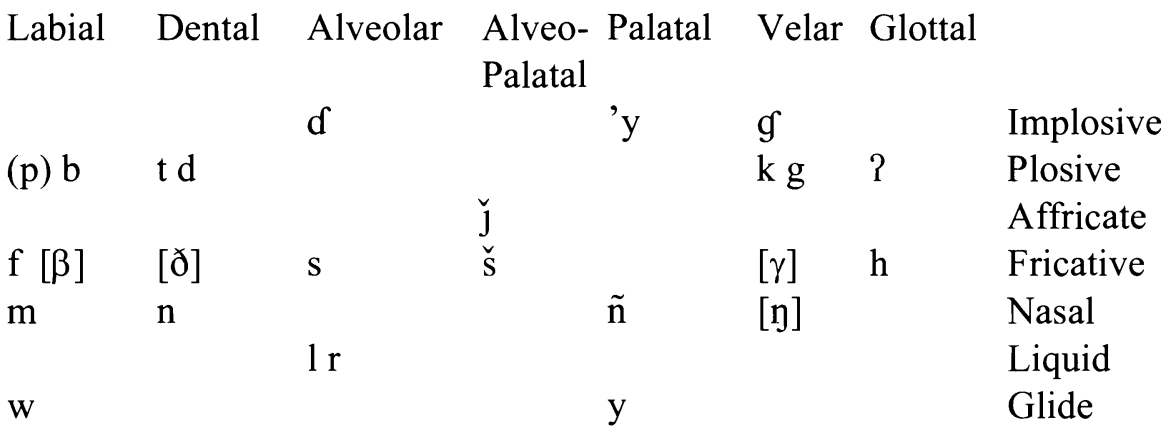

The alveolar and velar implosives [d] and [g] correspond to a voiced retroflex plosive [d] and voiceless uvular plosive [q], respectively, in both Standard and Central Somali. The palatal implosive ['y] may correspond to the voiced palatal stop [J] in Somali, though no cognates have been established to verify this. Though long consonants are documented in Standard and Central Somali, they are not found in LJM. In all cases where affixation would yield sequences of identical consonants, some process prevents these from surfacing. In the case of heteromorphemic sequences of any nasal $+n$, the first nasal always surfaces as [y], as in forms such as aay-ni 'we ate' (from underlying /aam-ni/). This could be 
analyzed as a dissimilatory process if we assume that the first nasal in such sequences first assimilates to the following $n$ via the regular assimilation process to be described in section 2.4., though such an analysis is admittedly somewhat abstract. Sequences of identical consonants other than $n$ are reduced to a single consonant. As in Central Somali (as discussed by Saeed 1982: 4), the phonological difference between underlying $\mathrm{C}_{\mathrm{i}} \mathrm{C}_{\mathrm{i}}$ vs. $\mathrm{C}$ is maintained among stops in intervocalic position since underlying singleton stops undergo weakening to fricatives whereas sequences of identical stops resist weakening. For example, input $/ \mathrm{k}+\mathrm{k} /$ surfaces as $[\mathrm{k}] \sim[\mathrm{g}]$ intervocalically, while input $/ \mathrm{k} /$ and $/ \mathrm{g} /$ surface as $[\gamma]$ in the same environment. This accounts for the difference between the intervocalic velar obstruents in [diiki] [diigi] 'the rooster' (from underlying $/ \mathrm{diik}+\mathrm{ki} /$ ) and [dißiyi] 'bull' (from underlying/dibigi/).

Though its consonants differ significantly from other dialects of Maay and Somali, the vowel inventory in LJM is identical to those of both Central and Standard Somali except that Saeed describes a sixth vowel in the short vowel inventory of Central Somali, a high central vowel, that does not seem to exist in LJM. The vowel inventory of LJM is presented below.

\section{Vowels of Lower Jubba Maay}

$\begin{array}{llll} & \text { Front } & \text { Central } & \text { Back } \\ \text { High } & \text { i } & & \text { u } \\ \text { Mid } & \text { e } & & \text { o } \\ \text { Low } & & \text { a } & \end{array}$

All five vowels have both long and short forms. As described by Saeed (1982, 1987) for Central and Standard Somali, corresponding long and short vowels in LJM have somewhat different qualities. In LJM, the short vowels in general are less widely dispersed in the vowel space than their long counterparts. This phonetic difference is not phonologically contrastive. Throughout this paper, I will use the five standard vowels to indicate both long and short vowels, but the phonetic difference in quality between long and short vowels should be kept in mind. On a related note, there is no evidence for a vowel harmony process in LJM like the one found in Standard Somali (Saeed 1987: 19, Armstrong 1934).

2.2 Tone or Accent. Hyman (1981), Saeed (1982, 1987), and Armstrong (1934) document contrastive tone and/or accent in some dialects of Somali. In Standard Somali, tone distinguishes not only lexical items, but also some grammatical 
categories such as case (Saeed 1987). However, no such effects of tone or accent are found in LJM. Stress is root-final, but it is not very prominent and is often not distinguishable at all, and the pitch profile of words is predictable based on the number and shape of syllables in the word and the position of the word in the sentence. Saeed (1982: 9) shows that in Central Somali (CS), tone is contrastive on noun roots. According to Saeed, most nouns have final high tone, while some disyllabic roots have initial high tone. As seen in the examples below, both patterns correspond to final stress in LJM. (3a) shows nouns with final high tone in CS and the corresponding final-stressed nouns in LJM (high tone is marked with an acute accent for the CS examples; stressed syllables in LJM are indicated by underlining the vowel). (3b) shows high-initial nouns in CS for which LJM cognates were found, and as can be seen here, the LJM cognates have final stress, not initial stress. ${ }^{1}$

(3)
$C S$
$L J M$
a. osbá
usbo
'salt'
boodá
boodo
'thigh'
(CS) / 'heel' (LJM)
dilmaañó
dilmaaño
'mosquito'
b. fárow
faro
ókun
okun
éyduur
eey duuret
'zebra'
'egg'
'wild dog'

In monosyllables, CS contrasts high vs. low tone. There is no such contrast in LJM; all monosyllables are produced with the same kind of word stress. Some examples are shown below (words with no acute accent in CS have low tone). Note that in some cases, tone distiguishes masculine nouns (4a) from feminine nouns (4b) in CS; this distinction is neutralized in the LJM cognates.

${ }^{1}$ While éyduur 'wild dog' is transcribed by Saeed (1982: 85) as a single word, the LJM cognate appears to be a noun phrase, eey duuret. In LJM, duuret is an adjective meaning 'wild', and is used in the names of other animals such as mukulal duuret 'wild cat' and loi duuret 'wild cow'. Because eey duuret has two roots, its stress pattern does conform to the root-final stress generalization. It should also be pointed out that the LJM nouns cited here are monomorphemic, despite the high frequency in this data set of final $o$ that might suggest that these words are morphologically complex. I believe the high frequency of $o$ here to be an accident resulting from the particular CS cognates cited by Saeed, since $o$ is not necessarily the most common final vowel in LJM. 
(4)

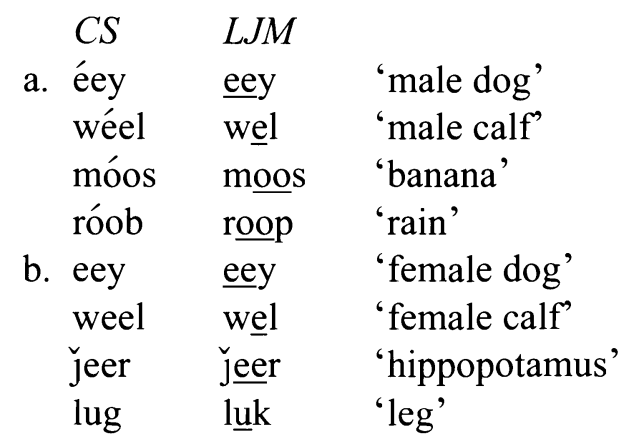

In addition to the lack of lexically contrastive stress, the case-marking function of tone in some Somali dialects is also absent in LJM. Saeed (1982) gives an example of two sentences distinguished by tone: úsa dîli 'he killed it' vs. usá dîli 'it killed him'. The two sentences are homophonous in LJM (usú dîli), since in LJM nouns are pronounced with the same pitch pattern regardless of their function in the sentence. Thus, the lack of case marking (whether by tones or segments) results in ambiguity in sentences where the subject and object would trigger the same verb agreement marking. To give another example, the sentences ii yahas aanti and yahas ii aanti can both mean either 'she ate a crocodile' or 'a crocodile ate her'. This is because the pronoun $i i$ 'she' and the noun yahas 'crocodile' are both feminine singular forms and therefore can both be the subject of the verb aan-t-i 'eat-Fem-Past'. The word order in LJM is relatively free with a preference for the verb to occur last, but in the sentences cited above, word order may be used to disambiguate the meaning, since the consultant first volunteers forms in which the subject occurs before the object (e.g., the consultant volunteers $i$ yahas aanti for 'she ate a crocodile' and yahas ii aanti for 'a crocodile ate her'). However, it is also possible that this is merely an effect of the word order in the English stimulus.

Saeed also reports that verbs exhibit characteristic tonal patterns in different morphological contexts in Central Somali (1982: 10). These are absent in LJM. Below are the forms of the Central Somali verb šeen 'bring' (Saeed 1982: 24-26) that have clear correspondents in LJM. Note that regardless of the location of the high tone in each Central Somali form, the root bears stress in the corresponding LJM form. 
(5)

$\begin{array}{ll}C S & L J M \\ \text { šéen-i } & \text { šeen-i } \\ \text { šeen-ə ̌́ér-i } & \text { šeen ǰir-i } \\ \text { šeen-óoy-ə } & \text { šeen-oy-e } \\ \text { šeen-é } & \text { šeen-e } \\ \text { šeen-ə dóon-ə } & \text { šseen donn-ya } \\ \text { šeen } & \text { šseen } \\ \text { šeen-ə́ } & \text { šeen-a }\end{array}$

'I brought' (simple past)

'I used to bring'

'I am bringing'

'I am about to bring'

'I will bring'

'bring!'

'bring! pl.'

I conclude that LJM is not a tonal language. It is unclear whether LJM has lost its tone or whether tonal contrasts were innovated in dialects spoken further to the north, but the former seems more likely since root-final stress is uniform in LJM and there is no obvious environment that would have conditioned a split into high vs. low tone in the northern and central dialects.

2.3 Root Shape and Loanword Adaptation. The largest native roots in LJM are three syllables; longer words appear to be affixed forms, compounds, or borrowings. Roots may begin with a consonant or a vowel (in the latter case, initial glottal stops are inserted to provide an onset when the preceding word does not end in a consonant). Roots may end with a consonant or vowel, though some segments are much more common than others in root-final position. For example, while many roots end in $/ \mathrm{m} /$, very few end in $/ \mathrm{n} /$, and it seems that no root ends in $/ \tilde{\mathrm{n}} /$ or $/ \mathfrak{y} /$ (though almost all nasal-final words have final [ $\mathrm{g}]$ on the surface due to a process to be described in section 2.4). Glottal stop is also very rare as a root-final segment. Impressionistically, among stem-final vowels, /e/, /o/, and /a/ are common while $/ \mathrm{i} /$ is somewhat less common and $/ \mathrm{u} /$ is rare.

The maximal syllable in LJM is CVVC. Consonant clusters are not permitted in onset or coda position. The longest sequences of consonants consist of two consonants, and these occur only intervocalically. The minimal syllable consists of a single short vowel, but no words of this shape are recorded; the smallest words have the shape VV (e.g., $i i$ 'she').

Loanwords have been identified as being borrowed from at least four different languages: English, Italian, Swahili (or other Bantu), and Arabic. The patterns of loanword adaptation provide evidence for the root and syllable structure generalizations mentioned above as being part of the grammar of the language rather than mere statistical generalizations. For instance, as seen in the examples below, consonant clusters in the source language are eliminated via vowel inser- 
tion or consonant deletion (inserted vowels are in bold type; sites of consonant deletion are underlined).

$\begin{array}{ll}\text { (6) } & \text { 'pasipor__ } \\ \text { taren } & \text { 'train' } \\ \text { kombuyuter } & \text { 'computer' } \\ \text { isbuña } & \text { 'sponge' (< It. spugna) } \\ \text { fiyus } & \text { 'fuse' } \\ \text { bol_ } & \text { 'bolt' } \\ \text { kareem } & \text { 'shaving cream' }\end{array}$

Borrowings from Arabic include ilbab 'door' (cf. St. Ar. el baab 'the door') and sa?at 'watch/clock' (cf. St. Ar. saSa, pl. sa@at); borrowings with a Bantu source include ñama 'meat' (cf. Proto-Bantu *nyama) and mateesa 'peanut'. Words borrowed from these languages undergo minimal changes, probably because the syllable structure restrictions of the source languages are similar to those of LJM.

2.4 Phonological Processes. LJM exhibits four major phonological processes that result in alternations: Nasal Place Assimilation, Final Nasal Velarization, Coronal Fusion, and Intervocalic Lenition. There is no crucial ordering or ranking of these processes, since no combination of them applies to the same type of sound in the same environment. The four processes are described below.

First, a process of Nasal Place Assimilation is observed, in which nasals agree in place of articulation with any immediately following consonant, in some cases resulting in alternations. This applies within words via both affixation (7a) and compounding ( $7 \mathrm{~b})$. The nasal-final roots are shown in both pre-consonantal (assimilating) and pre-vocalic (non-assimilating) contexts to give evidence for the underlying place of articulation of the nasal (in each of these cases, the underlying nasal is $/ \mathrm{m} /$; see below for further discussion).

(7)

\begin{tabular}{llll}
\multicolumn{2}{l}{ Pre-consonantal context } & Pre-vocalic context \\
a. ereñ-yal & 'goats' & erem-o & 'goats' \\
aan-ti & 'she ate' & aam-i & 'he ate' \\
dan-ti & 'she drank' & ani ina-dam-aw 'I might drink' \\
bilan-tew & 'which woman' & bilam-o & 'women' \\
saan-ti & 'the foot' & saam-o & 'feet' \\
gaPan-tey & 'my hand' & gaPam-o & 'hands' \\
minin-ki & 'the house' & minim-o & 'houses'
\end{tabular}



b. okun šalal
'egg and tomato dish' okum-o
'eggs'
inay gewer
'baby girl'
inam-o
'babies'
eren gondolo 'sheep'
erem-o
'goats'

The one exception to this generalization is that any nasal before $n$ surfaces as $\eta$, as discussed in section 2.1.

A second process in LJM, Final Nasal Velarization, affects the place of articulation of nasals: word-final nasals in LJM, as in Central Somali (Saeed 1982: 5) neutralize to [y]. A small number of exceptions have been found in LJM, but all of the exceptions found in this study were borrowed words, e.g., kareem 'shaving cream', dalafilin 'television', and broon 'brown'. Other nouns (including other borrowed words such as biy 'pin' from underlying /bin/ and balooy 'ball' from /baloon/) do undergo velarization, and the result of this in combination with the nasal assimilation rule discussed above is that the identity of a stemfinal nasal is generally only recoverable in plural forms with the $-o$ suffix. Below are examples of nouns with underlying $/ \mathrm{m} /(8 \mathrm{a})$ and $/ \mathrm{n} /(8 \mathrm{~b})$.

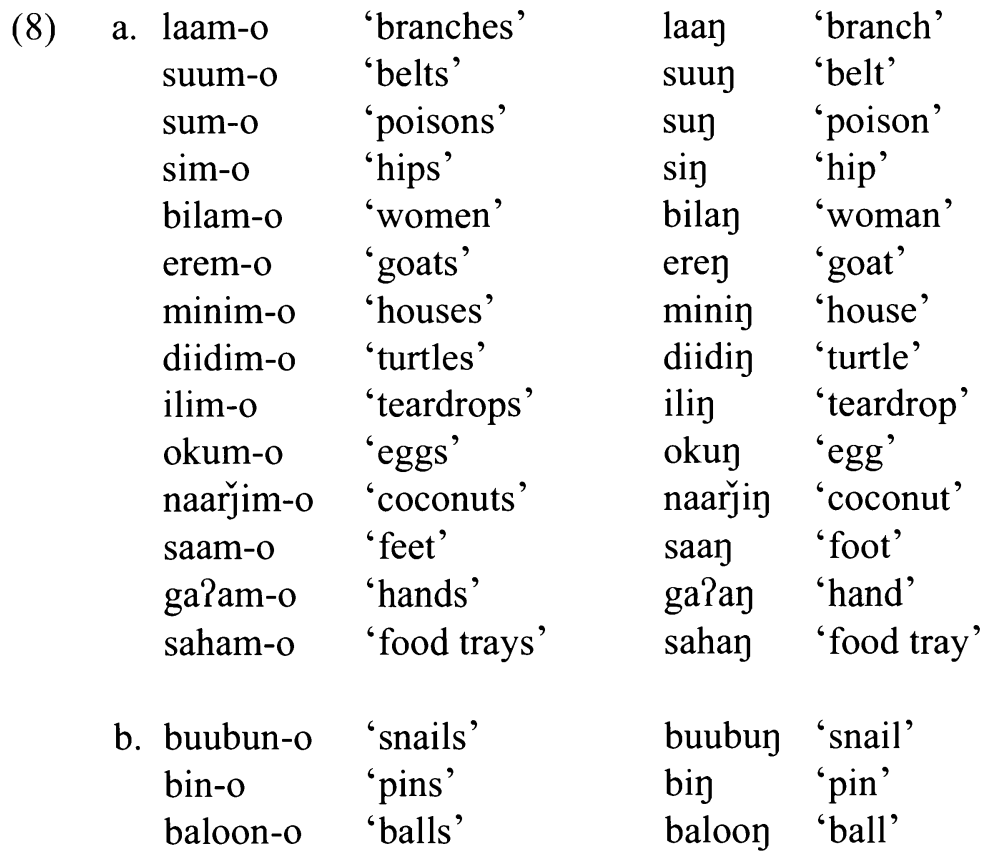

Interestingly, as is represented in the above data set, most nouns exhibit a single pattern: $[\mathrm{m}]$ in the plural form corresponds to $[\mathrm{y}]$ in the singular form. It is a very 
small number of words (e.g., 'snail' and 'pin') that establish the direction of the process seen here as $\{m, n\} \rightarrow \eta$ in uninflected forms, rather than $\eta \rightarrow m$ in the plural. It is possible that an analogical change is underway such that all of the nasal-final stems end in [m] in the plural form. Evidence for the change could include instances of stem-final [m] in LJM plurals corresponding to other, nonlabial nasals in Standard Somali. Unfortunately, several sources such as Luling (1987) list nouns in their singular forms, which may have undergone neutralization in the place of articulation of final nasals, and I have been able to establish only one LJM cognate with forms cited in sources that do indicate the precise identity of stem-final nasals (e.g., Kenstowicz 1994). The one example is LJM day 'affair' (pl. dam-o) corresponding to Somali dan/ dan-o (Kenstowicz 1994: 128). This example does support the hypothesis that stem-final nasals are changing to $/ \mathrm{m} /$ in LJM, but more examples are needed.

The domain of application for this rule does appear to be the word-final position, as opposed to, e.g., utterance-final position. As shown below, a word-final nasal surfaces as $/ \mathrm{y} /$ even when followed by a vowel in the following word, at least within the syntactic contexts represented in these examples (words exhibiting Final Velar Nasalization are indicated in bold). No examples were found in which a word-final nasal fails to undergo Final Nasal Velarization (except in the case of the specific exceptional words mentioned above).
nin-ki inay ili
man-det baby with play -pres.prog-3sgm.pres.prog
'the man is playing with a baby/child' (cf. inam-o 'babies')

eren eey-ki dini-'ye roor-oy -e

goat dog-det side-3sg run -pres.prog-3sgm.pres.prog

'a goat is running beside/behind the dog' (cf. erem-o 'goats')

baloon inạ-ki dariša -ði ka 'ye $\beta-i$

ball baby-det window-det inst. break-3sgm.past

'the baby/child broke the window with a ball'2 (cf. baloon-o 'balls')

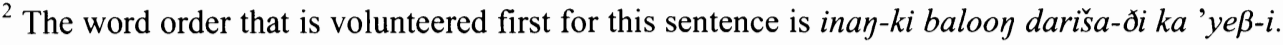
However, the sentence presented here (selected in order to provide the pre-vocalic context for the final nasal of baloon) is also accepted by the consultant, along with corresponding sentences exhibiting four additional possible orders for a total of six.
} 
A third phonological process of LJM is Coronal Fusion. LJM differs from both Central and Standard Somali in its treatment of $/ 1+t /$. In Central Somali, $/ 1+t /$ becomes [11] (Saeed 1982: 5). In Standard Somali, these consonants fuse into [̌̌ when the / $t /$ belongs to an inflectional suffix (Saeed 1987: 24) (this is very often the case, since all of the inflectional suffixes with feminine agreement begin with $/ \mathrm{t} /$, as will be discussed below). The result of the Standard Somali fusion process is seen in possessed forms of walaal 'sister' in LJM, as seen below (all possessive suffixes have underlying initial/t/ when the possessed noun is feminine).

\begin{tabular}{|c|c|c|c|}
\hline $\begin{array}{l}\text { (10) walaaš-ey } \\
\text { walaaš-a } \\
\text { walaaš-is } \\
\text { walaaš-ie }\end{array}$ & $\begin{array}{l}\text { 'my sister' } \\
\text { 'your sister' } \\
\text { 'his sister' } \\
\text { 'her sister' }\end{array}$ & $\begin{array}{l}\text { walaaš-aynu } \\
\text { walaaš-in } \\
\text { walaaš-io } \\
\text { walaaš-i }\end{array}$ & $\begin{array}{l}\text { 'our sister' } \\
\text { 'your pl. sister' } \\
\text { 'their sister' } \\
\text { 'the sister' }\end{array}$ \\
\hline
\end{tabular}

It appears that walaal is exceptional in undergoing this process, since all other $/ 1+t /$ sequences that were elicited in LJM reduce to [l] instead of [š]. Examples are shown below; all nouns in this set are feminine, and therefore, as will be explained in section 3.2 , the suffixes have underlying initial $/ \mathrm{t} / \mathrm{.}^{3}$

$\begin{array}{llll}\text { (11) } \begin{array}{l}\text { weel } \\ \text { weel-ey }\end{array} & \begin{array}{l}\text { 'calf' } \\ \text { 'my calf' } \\ \text { 'your-a calf' }\end{array} & \begin{array}{l}\text { hambal } \\ \text { hambal-ey } \\ \text { hambal-a } \\ \text { 'the calf' }\end{array} & \begin{array}{l}\text { 'leaf' } \\ \text { 'my leaf' } \\ \text { 'your leaf' } \\ \text { 'the leaf' }\end{array} \\ \begin{array}{l}\text { 'yonfol } \\ \text { 'yonfol-ey }\end{array} & \begin{array}{l}\text { 'bark' } \\ \text { 'my bark' }\end{array} & \begin{array}{l}\text { mukulal } \\ \text { mukulal-ey }\end{array} & \begin{array}{l}\text { 'cat' } \\ \text { 'my cat' }\end{array} \\ \text { 'yonfol-a } & \text { 'your bark' } & \text { mukulal-a } & \text { 'your cat' } \\ \text { mukulal-i } & \text { 'the cat' } \\ \text { kaal } & \text { 'the bark' } & \text { il } & \text { 'eye' } \\ \text { kaal-ey } & \text { 'spoon' } & \text { il } & \text { 'my spoon' } \\ \text { kaal-a } & \text { 'your spoon' } & \text { il-ey } & \text { 'my eye' } \\ \text { kaal-i } & \text { 'the spoon' } & \text { il-i } & \text { 'your eye' }\end{array}$

${ }^{3}$ The fact that these are feminine nouns is evident when they are contrasted with masculine $l$ final stems, which take $k$-initial masculine-agreeing suffixes: alol-key 'my tray', baskil-key 'my bicycle', shawel-key 'my tiger', hel-key 'my nut', jornal-key 'my newspaper', and nalkey 'my light'. 
This process can be thought of in two different ways. It could be analyzed as assimilation of / $t /$ to an immediately preceding /1/ (as in Central Somali) followed by the application of the weakening process (already motivated in LJM) that reduces geminates to singletons. In this view, the reduction of $/ 1+t /$ to [l] would take place in two steps: $l t \rightarrow l l \rightarrow l$. Alternatively, one could analyze this as simply a single process that deletes $/ \mathrm{t} / \mathrm{after} / \mathrm{l} /$. One advantage of the two-step analysis is that each step is independently motivated (though the first step is motivated in a different dialect); on the other hand, there is no direct evidence for the intermediate stage $l l$. The alternative one-step proposal does not have this problem, and furthermore, it seems likely to be the analysis posited by the language learner since $/ 1+t /$ apparently always surfaces as [1] in regular forms (except in forms of walaal). Therefore, I will assume that the reduction of $/ 1+\mathrm{t} /$ is the result of a single rule deleting $/ t /$ in this environment.

A final phonological process to be discussed here is Intervocalic Lenition. As was mentioned earlier in the discussion of underlying geminates vs. singleton consonants, stops in LJM occur as voiced fricatives at the same place of articulation when they are in intervocalic position. The resulting alternation can be observed in the examples below, where suffixation of the plural marker $-o$ to a stem ending in a stop provides the intervocalic context that triggers lenition. ${ }^{4}$

\begin{tabular}{|c|c|c|c|}
\hline (12) geet & 'tree' & geeð-o & 'trees' \\
\hline belet & 'city' & beleð-o & 'cities' \\
\hline irbit & 'needle' & irbið-o & 'needles' \\
\hline hidik & 'star' & hidi $\gamma-0$ & 'stars' \\
\hline diik & 'rooster' & dii $\gamma-o$ & 'roosters' \\
\hline buuk & 'book' & buu $\gamma-\mathrm{o}$ & 'books' \\
\hline luk & 'leg' & lu $\gamma-o$ & 'legs' \\
\hline dek & 'ear' & de $\gamma-0$ & 'ears' \\
\hline harak & 'rope' & haray-o & 'ropes' \\
\hline kasap & 'sugar cane' & kasa $\beta$-o & 'sugar canes' \\
\hline ilbap & 'door' & ilbaß-o & 'doors' \\
\hline kop & 'cup' & ko $\beta-\mathrm{o}$ & 'cups' \\
\hline
\end{tabular}

${ }^{4}$ Note that although some roots are transcribed with final voiced obstruents while others have final voiceless obstruents, there is apparently no voicing contrast root-finally. No minimal or near-minimal pairs have been found that would motivate such a contrast. I have therefore reproduced these examples just as I transcribed them. Word-final dental stops tend to sound like $[\mathrm{t}]$, and word-final velars sound like $[\mathrm{k}]$, while word-final labial stops vary between $[\mathrm{b}]$ and $[\mathrm{p}]$. All are unreleased word-finally. 
The reason for assuming that these words have underlying final stops that change to fricatives rather than vice versa is that voiced fricatives have a more limited distribution than do stops in LJM. Voiced fricatives occur only intervocalically, whereas stops occur word-initially, word-finally, and in syllable-final position before another consonant. Stops do also occur intervocalically in words such as diiki 'rooster', but recall from section 2.1 that the [k] in this form corresponds to underlying $/ \mathrm{k}+\mathrm{k} /$, so the presence of surface intervocalic stops results from the fact that geminate reduction applies after intervocalic lenition (reduction counterfeeds lenition).

Intervocalic lenition does not always apply; it is variable, but at least in morphologically derived contexts, application of the rule is always possible. There are some monomorphemic words within which the rule will never apply, even optionally. For example, in the data set above, the word [hidik] always surfaces with medial [d], never [ð]. A possible explanation for this is that the word has an underlying medial geminate, i.e. /hiddik/, and that the /dd/ reduces to [d] on the surface. There is no external evidence for $/ \mathrm{dd} /$, but this does solve the problem of non-application in words of this type, and it is consistent with the doubled consonant reduction pattern that we already know to exist in the language.

\section{Noun Morphology.}

The noun morphology of LJM exhibits a number of interesting characteristics, such as an unusual pattern of plural marking that includes optional phonologically licensed multiple plural marking, and an interesting interaction between number and gender. Markers modifying singular feminine nouns have initial $/ t /$, while the masculine correspondents generally have initial $/ \mathrm{k} /$ with a few principled exceptions. The gender distinction is motivated by the fact that nouns referring to female humans and animals take suffixes beginning with / $t$ /, while nouns referring to male humans and animals take suffixes beginning with $/ \mathrm{k} /$, and all other nouns pattern arbitrarily in the suffixes that they take, regardless of their phonological shape, semantics, or any other grammatical factor. Nouns taking $t$-initial suffixes include words corresponding to English 'woman', 'mother', 'girl', 'grandmother', 'daughter', 'female cow', 'female dog', and also 'knife', 'crocodile', 'napkin', 'foot', 'finger', 'leg'. Nouns taking $k$-initial suffixes include words corresponding to 'man', 'father', 'boy', 'grandfather', 'son', 'brother', 'bull', 'male dog', and also 'bicycle', 'cup', 'rabbit', 'tree', 'head', 'mouth', and 'thigh'. A 
noun can have masculine or feminine gender agreement with a corresponding meaning change, e.g., eey- $k i$ 'the (male) dog' vs. eey- $t i$ 'the female dog'.

The $t$ vs. $k$ distinction is so prevalent that one could call them agreement markers and factor them out from the grammatical markers that include them (definite markers, demonstratives, and possessive markers). For example, we could assume that the definite marker does not have two underlying forms, feminine /-ti/ and masculine /-ki/, but rather that it has a single form /-i/, which can be preceded by a feminine agreement marker / $\mathrm{t} /$ or a masculine agreement marker $/ \mathrm{k} /$, yielding the surface forms $-t i$ and $-k i$. In the examples below, I have not included morpheme breaks after these 'gender agreement' markers, but one could assume that these are, in fact, separate morphemes. ${ }^{5}$

3.1 Number. LJM exhibits phonologically conditioned suppletive allomorphy (PCSA) in the plural marking. Plural is marked by two suffixes, $-o$ and -yal. All vowel-final stems take the $-y a l$ suffix; they cannot take the $-o$ suffix. Examples are shown below.

$\begin{array}{ll}\text { (13) } \begin{array}{l}\text { šati } \\ \text { buundo }\end{array} & \text { 'shirt' } \\ \text { mindi } & \text { 'knidge' } \\ \text { baaka } & \text { 'box' } \\ \text { aweesa } & \text { 'worm' } \\ \text { liwa } & \text { 'lion' } \\ \text { kora } & \text { 'small monkey sp.' } \\ \text { deji } & \text { 'snake' } \\ \text { bakaile } & \text { 'rabbit' } \\ \text { muata } & \text { 'duck' } \\ \text { raka } & \text { 'frog' } \\ \text { mateesa } & \text { 'peanut' } \\ \text { maða } & \text { 'head' } \\ \text { indo } & \text { 'eye' } \\ \text { bakeeri } & \text { 'cup' }\end{array}$

$\begin{array}{ll}\text { šati-yal } & \text { 'shirts' } \\ \text { buundo-yal 'bridges' } \\ \text { mindi-yal } & \text { 'knives' } \\ \text { baaka-yal } & \text { 'boxes' } \\ \text { aweesa-yal } & \text { 'worms' } \\ \text { liwa-yal } & \text { 'lions' } \\ \text { kora-yal } & \text { 'small monkey sp.' } \\ \text { deji-yal } & \text { 'snakes' } \\ \text { bakaile-yal 'rabbits' } \\ \text { muata-yal 'ducks' } \\ \text { raka-yal 'frogs' } \\ \text { mateesa-yal 'peanuts' } \\ \text { maða-yal 'heads' } \\ \text { indo-yal 'eyes' } \\ \text { bakeeri-yal 'cups' }\end{array}$

${ }^{5}$ There are two main reasons why I have not indicated separate gender agreement morphemes. The first is mere notational convenience. The second is that, as will be seen, there are two problematic possessive markers that do not exhibit the usual $t$ vs. $k$ agreement pattern. Though the small number of exceptional morphemes does not necessarily disprove the gender agreement marker hypothesis, I have elected not to use a type of notation that would require a synchronic explanation for these exceptional forms. 
At first, the distribution of the two plural suffixes might appear to be a neat complementary one, with vowel-final stems taking -yal and consonant-final stems taking $-o$. And, in fact, plural forms with $-o$ are usually volunteered first when the consultant is asked to pluralize consonant-final nouns. However, the situation is more complicated, in that there are three ways to form a plural for any consonantfinal stem. As seen in (14), consonant-final stems can take not only -o, but also $y a l$, or the combination of $-o$ followed by $-y a l$.

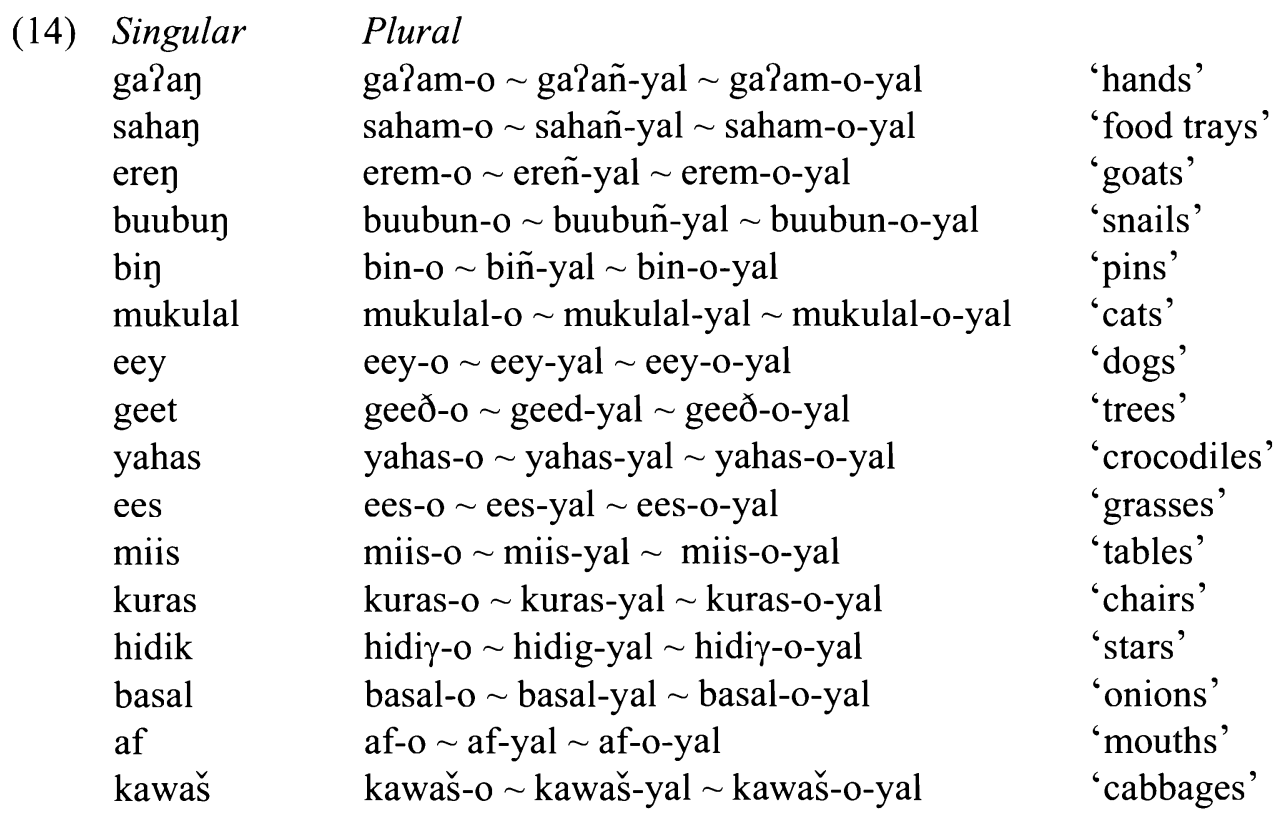

The consultant reports that there is no meaning difference among plurals formed in each of these three different ways. Although the forms with - $o$ tend to be volunteered first (though this is not always the case), all three forms are judged by the consultant to sound equally good. The examples in (15) confirm that there is no difference in the function of the different types of plural nouns, since each can be a subject or object. 
$\begin{array}{llll}\text { (15) a. } & \text { eey-o } & \text { usu } & \text { dil-eena } \\ & \text { dog-pl } & \text { 3sgm } & \text { kill-3pl.past } \\ & \text { 'dogs killed him' } & \end{array}$

eey-yal usu dil-eena

dog-pl 3sgm kill-3pl.past

'dogs killed him'

eey-o-yal usu dil-eena

dog-pl-pl 3sgm kill-3pl.past

'dogs killed him' dil-i

kill-3sgm.past

3sgm dog-pl
'he killed dogs' $\begin{array}{ll}\text { usu } \quad \text { eey-yal } & \text { dil-i } \\ \text { 3sgm dog-pl } & \text { kill-3sgm.past } \\ \text { 'he killed dogs' } & \end{array}$

usu eey-o-yal dil-i

3sgm dog -pl-pl kill-3sgm.past

\begin{abstract}
yahas -o usu aam-eena
crocodile-pl 3sgm eat -3 pl.past

'crocodiles ate him'
\end{abstract}

yahas -o-yal usu aam-eena

crocodile-pl-pl 3sgm eat -3pl.past

'crocodiles ate him'

usu yahas -o aam-i

$3 \mathrm{sgm}$ crocodile-pl eat -3 sgm.past

'he ate crocodiles'

usu yahas -yal aam-i

3sgm crocodile-pl eat -3sgm.past

'he ate crocodiles'

usu yahas -o -yal aam-i

3 sgm crocodile-pl-pl eat -3 sgm.past 'he ate crocodiles'

The existence of three different plurals for all consonant-final stems is unusual and also problematic for some ideas in morphology, e.g. the treatment of blocking. Any theory of morphology must account for how, e.g., lexicalized forms block the production of regular inflected forms. Often the notion of economy has been invoked, so that the form with the smallest number of morphemes is always selected to convey any given set of meanings. For example, in English, the already plural sheep prevents the morphology from producing * sheeps because sheep already conveys the semantics of the noun plus the plural all in one morpheme, so using two morphemes $($ sheep $+s$ ) would be uneconomical in comparison, and this is therefore ruled out. If this economy principle were a real property of grammars, we would expect it to extend to cases where there is a choice between a form in which a morphological category is marked by a single affix vs. a form where the same category is multiply exponed. Although economy would allow for the optional use of one affix or another to mark a particular cate- 
gory plural (e.g., in Maay, -o vs. $-y a l$ ), it also predicts that that simple affixation should always win out over multiple exponence, so that multiply marked forms such as the Maay plurals in -o-yal should be blocked by the existence of forms in - $o$ and forms in -yal. ${ }^{6}$ To allow for -o-yal plurals, one could assume that the economy requirement is not universally obeyed but is rather a violable constraint in the Optimality Theory sense. However, this would significantly weaken the economy concept, which has been invoked as an inviolable filter on surface forms in the analyses of many different languages. The problem of multiple plural marking therefore warrants further study.

It should be noted that there is no evidence in LJM for declension classes, unlike in some dialects of Somali (see e.g. Hyman 1981, Saeed 1987, Lecarme 2002). In LJM, the only division in nouns with respect to plural marking is between consonant- vs. vowel-final stems, and all nouns not following this pattern appear to be irregular rather than forming any additional classes. Nouns that in other dialects have plural forms other than -o or $-y a l$ do take these regular suffixes in LJM. For example, in the Somali dialect described by Lecarme, the noun ey 'dog' takes a 'prosodic plural', meaning that the plural is marked by a tone shift, while the noun $a f^{\text {' }}$ mouth' takes an 'internal $-a$ - plural', which is a suffixed partial reduplicant with a fixed /a/ in place of the stem vowel (2002: 116-117). In LJM, both of these nouns take regular plural marking: eey-o $\sim$ eey-yal $\sim$ eey-o-yal 'dogs'; af-o $\sim a f-y a l \sim a f-o-y a l$ 'mouths'.

Another interesting fact about plurals in LJM is that adjectives can optionally exhibit plural marking in a complex noun phrase. There are a variety of ways in which this can be manifested, as seen in the examples below.

${ }^{6}$ As discussed below, there is some evidence that while $-o$ is a suffix, $-y a l$ is a clitic. One might therefore argue that the multiple plural marking is not problematic because it involves marking by two different types of morphemes rather than by two suffixes. However, blocking does not seem to differentiate between affixes and clitics. For example, in English, the possessive -' $s$ has been analyzed as a clitic while the plural $-s$ is a suffix. But forms like *my's are blocked by the existence of lexical (monomorphemic) possessives like mine in just the same way that the plural form *womans is blocked by women. Therefore, it is not clear that invoking the difference between affixes and clitics will solve the problem of multiple plural marking here. 
(16) a. Mass noun/ inherent plural with unmarked adjective moos yaale 'yellow bananas' banana(s) yellow

b. Mass noun/ inherent plural with reduplicated adjective det fa-fas 'beautiful people' people pl-beautiful

c. Mass noun/ inherent plural with adjective ending in -yal barada kulel-yal 'hot potatoes' potato(es) hot-pl

d. Noun ending in -o with unmarked adjective geeð-o ayar 'green trees' tree-pl green

e. Noun ending in -o with reduplicated adjective geeð-o de-deer 'tall trees' tree-pl pl-tall

f. Noun ending in -o with adjective ending in -yal geeð-o ayar-yal 'green trees' tree-pl green-pl

g. Noun ending in -yal with unmarked adjective megel-yal deer 'tall men' man-pl tall

h. Noun ending in -yal with reduplicated adjective megel-yal de-deer 'tall men' man-pl pl-tall

i. Noun ending in -o-yal with unmarked adjective geeð-o-yal ayar 'green trees' tree-pl-pl green

j. Noun ending in -o-yal with reduplicated adjective geeð-o-yal mo-moon 'big trees' tree-pl-pl pl-big

We have already seen that (consonant-final) nouns can be pluralized by using either $-o$ or $-y a l$, or a combination of both, and in addition there are some mass nouns and inherent plurals that do not need an affix to convey plural meaning. Adjectives that modify a plural noun do not have to have plural marking, but when they do, they can either undergo prefixing reduplication or they can take $-y a l$ (this suggests that $-y a l$ may be better analyzed as a clitic rather than a suffix since it does not have to occur immediately next to the noun; $-o$, on the other 
hand, must always occur next to the noun). The combination of four types of plural nouns (mass nouns/ inherent plurals, -o, -yal, and -o-yal) with three types of adjectives that can modify them (no marking, reduplication, and -yal) should yield twelve possibilities for plural noun phrases with a noun + adjective. However, as seen above in examples $(16 \mathrm{a}-\mathrm{j})$, only ten of these possibilities are attested. The two unattested possibilities are a noun with -yal followed by an adjective with -yal, and a noun with -o-yal followed by an adjective with -yal. Both can be ruled out by a restriction that the same plural marking cannot be used more than once in the same noun phrase.

My analysis of this situation is that the plural marking on adjectives is not agreement per se, but is rather overt plural marking just like plural marking on nouns. There are three ways that the morphology can mark plural in a noun phrase: the suffix -o, the clitic -yal, and reduplication. At least one of these must be used within the noun phrase to make it plural (unless the noun is already inherently plural). All of these can co-occur, but each can only be used once within a single noun phrase. The suffix $-o$ is restricted to occurring with noun roots, and reduplication can apply only to adjectives; -yal, on the other hand, can occur next to either a noun or a noun phrase. The interaction of these requirements yields the observed patterns of plural noun phrases with a noun + adjective.

3.2 Gender. All nouns in LJM have either masculine or feminine gender. In the noun phrase, gender agreement is manifested in the definite marker, demonstratives, and possessive markers. Examples of these will be given in sections 3.3, 3.4 , and 3.5, respectively. In each case, where the masculine form of the marker has initial $/ \mathrm{k} /$, the feminine form of the marker has initial $/ \mathrm{t} /$. The pattern is consistent for all of the grammatical markers mentioned above with two exceptions: the $3 \mathrm{sg}$ masculine possessor of a masculine noun has the form -'ye rather than the form *-kie which would be expected since its feminine-agreeing counterpart is -tie, and similarly, the $3 \mathrm{pl}$ masculine-agreeing possessor has the form -'yo rather than the expected $-k i o{ }^{7}$

Though there are two genders in singular forms of nouns, all nouns trigger

${ }^{7}$ But note that these could derive historically from *-kie and *-kio via a series of sound changes ${ }^{*} k i>{ }^{*}{ }_{J}>{ }^{\prime} y$, where $k$ and $i$ merge into a palatal $j$ which later changes to ' $y$. The change from $f$ to ' $y$ is plausible since we know that the other two stop sounds of Standard Somali that are absent from the inventory of LJM (namely, $d$ and $q$ ) correspond to implosives ( $d$ and $g$, respectively) in LJM. Further evidence in favor of *-kie and *-kio as the respective sources of LJM -'ye and -'yo is that the corresponding Standard Somali forms do begin with [k]: -kiisa and -kooda (Saeed 1999: 115). 
masculine gender agreement when they are pluralized. This is true regardless of the way in which the plural is formed (for consonant-final stems that have three different plural forms). As seen in the examples below, nouns that take feminine agreement when in the singular form take masculine agreement in the plural. The feminine-agreeing suffixes all have allomorphs beginning in [t], [ð], and $\varnothing$, distributed as follows: [ð] occurs when the stem ends in a vowel (or ?, though there is only one example of this, which could possibly be an exception), $\varnothing$ occurs when the stem ends in $t / d$ or $l$, and [t] occurs elsewhere. Similarly, the masculineagreeing suffixes begin with $[\gamma]$ when the stem ends in a vowel, $\varnothing$ when the stem ends in $\mathrm{k} / \mathrm{g}$, and [k] elsewhere.

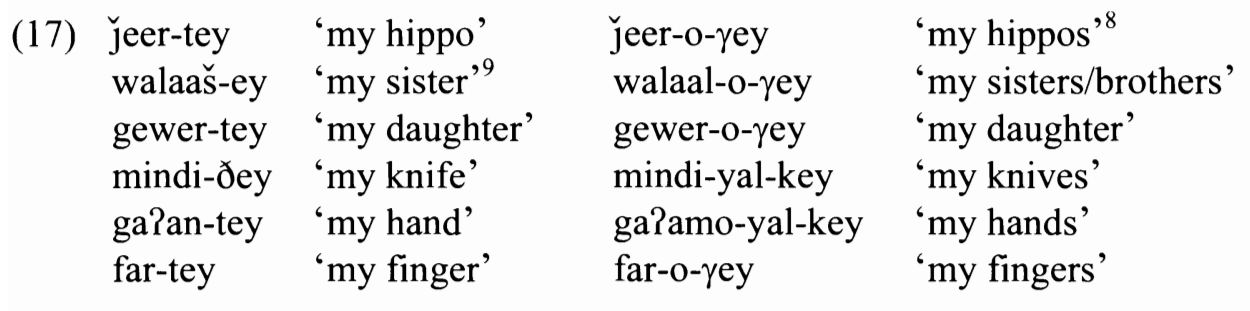

As seen below, there is no change to masculine nouns in the plural; they retain masculine agreement.

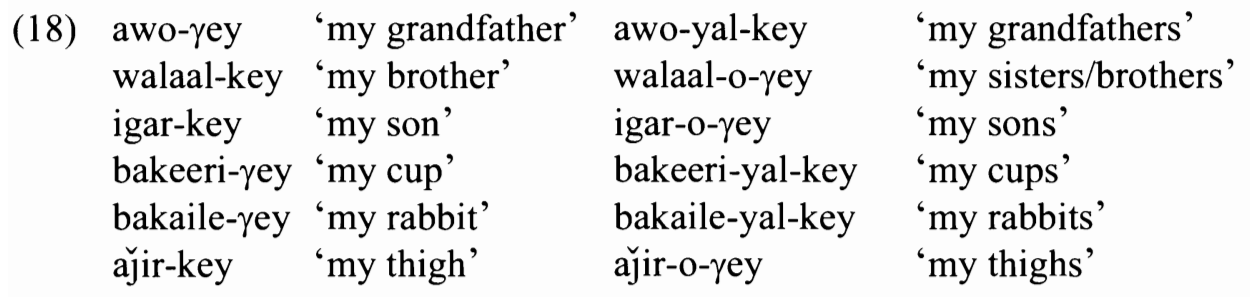

\footnotetext{
${ }^{8}$ For this and all other forms in my data (with no exceptions), the possessive suffix can be added to a plural noun made in any of the three ways that are possible for consonant-final stems. For example, in addition to jeer-o-yey, 'my hippos' can also be jeer-yal-key or jeer-oyal-key. Here I will give only the possessed plurals formed with -o for consonant-final stems.

${ }^{9}$ The form walaaš-ey comes from /walaal-tey/; /1+t/ fuses into [̌̌] here as described above in section 2.4. We know that this form has feminine agreement in the 1 sg possessive suffix (i.e., that the suffix is /-tey/ rather than the masculine /-key/) because the initial $/ \mathrm{k} /$ of the masculine form would not fuse with stem-final $/ 1 /$. This is apparent in the word 'brother', which differs from 'sister' only in its gender; the form meaning 'my brother' is walaal-key.
} 
A point of interest here is that in at least one case, the neutralization of the gender distinction in the plural leads to ambiguity. In the singular, the words meaning 'brother' and 'sister' are homophonous (walaal) and are distinguished only via agreement, as in walaaš-ey 'my sister' vs. walaal-key 'my brother' (see footnote 3 ). In the plural, since both take masculine agreement, the form walaal-o-yey has two possible interpretations: it can mean 'my sisters' or 'my brothers'.

The relationship between gender and number in LJM is different not only from Standard Somali but also from the more closely related Central Somali. Standard Somali exhibits a phenomenon known as 'gender polarity' in which 'most nouns reverse their gender when they become plural' (Saeed 1987: 115). This applies to both masculine and feminine nouns and is true of plurals formed with $-o$ or with $-y a l$, so the identity of the plural suffix does not condition polarity. (Unlike in LJM, the choice of plural suffixes in Standard Somali is determined by the noun's 'declension class'.) In Central Somali (as in Standard Somali), the choice between - $o$ and -yal is determined by declension class, but in Central Somali, only plurals with -o exhibit true polarity. Plurals with -yal exhibit a different pattern in which all nouns are masculine in the plural. Thus, there is gender reversal when the singular noun is feminine since it becomes masculine in the plural, but there is no change when a singular masculine noun is pluralized. LJM exhibits a third variation on the gender polarity theme: as demonstrated above, all plurals are masculine regardless of whether the plural is formed with -o or $-y a l$. There is no evidence for declension classes in LJM; as has been shown above, all vowelfinal stems take - $o$ plural marking regardless of their gender, while all consonantfinal stems can take -o, -yal, or -o-yal regardless of their gender. In the unidentified Somali dialect discussed by Lecarme (2002), there is yet a fourth variation: plurals in $-y a l$ exhibit true polarity, while plurals in - $o$ are all masculine (Lecarme 2002: 118-119) (i.e., the reverse of the Central Somali pattern). ${ }^{10}$ It would seem that LJM is the most innovative of the dialects, since the existence of gender polarity in other Cushitic languages (e.g. Oromo (Andrzejewski 1960) and Rendille (Oomen 1981)) suggests that it is an old feature. If gender polarity was a feature of the common ancestral language of Somali and Maay, then Central Somali has undergone a change in the -yal plurals, while the dialect described by Lecarme

${ }^{10}$ The situation is more complicated in this dialect than I have represented it, in that there are more than two ways to form plurals. The reader is referred to Lecarme (2002) for more details as well as a theoretical analysis of gender polarity in the Distributed Morphology framework. 
(2002) has undergone a change in the -o plurals, and LJM exhibits the same change in both types of plurals.

3.3 Definiteness. Whereas Central and Standard Somali have remote (past or physically far away) vs. non-remote (present or future) definite marking on nouns (Saeed 1982, 1987), LJM has only one set of definite markers, -ki/-ti. These are cognates with the Standard Somali and Central Somali remote/past definite markers. They exhibit gender agreement with nouns, as seen below.

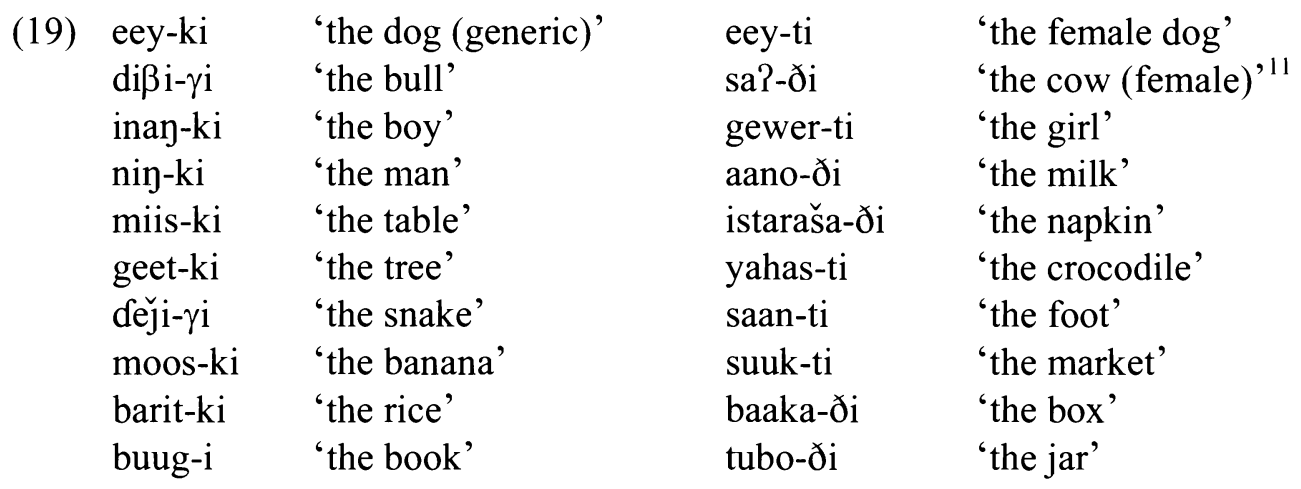

As mentioned above, all nouns trigger masculine agreement in the plural. The definite marker obeys this generalization: as demonstrated below, the definite marker $/-\mathrm{ki}$ / is used for plural nouns regardless of whether the singular form is masculine $(20 \mathrm{a})$ or feminine $(20 \mathrm{~b})$.

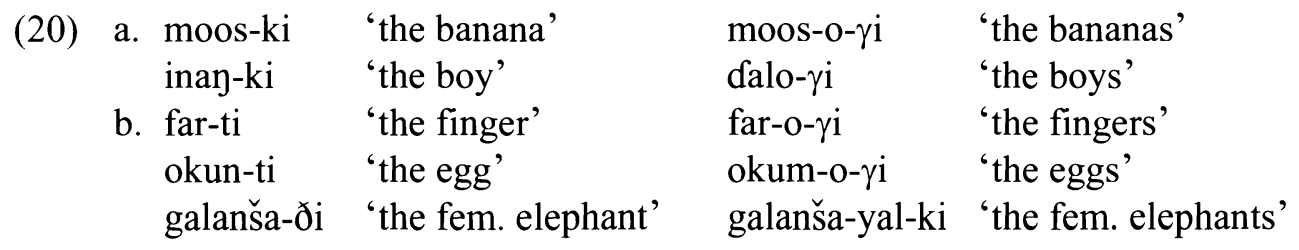

${ }^{11}$ This is the one exception in my data to the generalization that the voiced fricatives occur only intervocalically. The noun in isolation does have a final glottal stop ([sa?] 'cow'), so there is no evidence for an underlying root-final vowel. Perhaps glottal stops are transparent to the intervocalic lenition process described in section 2.4. Word-final glottal stops are very rare, so it has not yet been possible to test the hypothesis that glottal stops are transparent to lenition. 
Though the notation in the examples above implies that the definite markers are suffixes, there is evidence to suggest that they are instead clitics. The evidence for this is that in a noun phrase consisting of a noun + adjective, the definite marker occurs after the adjective, as seen in the examples below.

(21)

geet deer-ki

baaka geðud-i 'the tall tree'

'the red box'

Note that these are not analyzable as agreement markers, since only one instance of the definite marker is permitted for a given noun phrase (thus, the forms * geet$k i$ deer-ki and *baaka-ði geðud-i are ungrammatical).

3.4 Demonstratives. There are three demonstratives in LJM, corresponding to 'this', 'that', and 'which...?'. Each exhibits the same $t$ - vs. $k$ - gender agreement pattern as in the definite markers described above. Examples of masculineagreeing demonstrative markers are shown below.
(22)

$\begin{array}{llll}\text { eey-kay } & \text { 'this dog', } & \text { buug-an } & \text { 'this book' } \\ \text { eey-kas } & \text { 'that dog' } & \text { buug-as } & \text { 'that book' } \\ \text { eey-kew } & \text { 'which dog' } & \text { buug-ew } & \text { 'which book' }\end{array}$
geet-kan 'this tree',
megel-kan 'this man'
geet-kas 'that tree'
megel-kas 'that man'
geet-kew 'which tree'
megel-kew 'which man'

Examples of feminine-agreeing demonstrative markers are shown below with feminine nouns in the singular form.

(23)

yahas-tan

'this crocodile'

istaraša-ðay 'this napkin'

yahas-tas

'that crocodile'

istaraša-ðas 'that napkin'

yahas-tew

'which crocodile'

istaraša-ðew 'which napkin'

mukulal-an 'this cat'

bilaan-tan

'this woman'

mukulal-as 'that cat'

bilaan-tas

'that woman'

mukulal-ew 'which cat'

bilaan-tew

'which woman' 
Like the definite markers, the demonstrative markers always take the masculine form when the noun is plural, even when the singular form of the noun is feminine, as in the examples below.

\section{(24)}
yahas-o- $\gamma$ an
'these crocodiles'
istaraša-yal-kạ
'these napkins'
yahas-o- $\gamma$ as
'those crocodiles'
istaraša-yal-kas
'those napkins'
yahas-o- $\gamma$ ew
'which crocodiles'
istaraša-yal-kew
'which napkins'
mukulal-o- $\gamma$ an 'these cats'
mukulal-o- $\gamma$ as 'those cats'
bilaam-o- $\gamma$ an
mukulal-o-rew 'which cats'
bilaam-o- $\gamma$ as
'these women'
'those women'
bilaam-o- $\gamma$ ew
'which women'

Also like the definite markers, demonstratives in LJM appear to be clitics since in complex noun phrases they occur at the end of the phrase rather than immediately after the noun, as in the examples below.

(25) geet gab-kay
geet deer-kay
baaka geðud-as

However, as with the definite markers, there cannot be multiple instances of the demonstrative marker within the same noun phrase. Phrases such as *geet-kay gab-kay are ungrammatical, which shows that demonstrative marking on an adjective is not simply agreement with the noun.

3.5 Possessives. Possessive marking exhibits the same gender agreement pattern as the definite and demonstrative markers, including the pattern of all-masculine agreement in the plural forms discussed in section 3.2. Some examples of masculine possessed nouns are shown below. ${ }^{12}$

\footnotetext{
${ }^{12}$ Forms given here for 'her $\mathrm{X}$ ' are in the regular masculine agreement form, but there is an interesting effect where (apparently) all masculine nouns can optionally take -tie instead of the expected -'ye. That is, when the 3sg possessor is feminine, the feminine-agreeing suffix can optionally be used with a masculine noun. The effect is only found in the $3 \mathrm{sg}$, and it does not apply in the opposite direction (i.e., the masculine-agreeing 3sg masculine suffix -'ye cannot be used for 'his $\mathrm{X}$ ' where $\mathrm{X}$ is a feminine noun; instead, the feminine-agreeing -tis must be used).
} 


\begin{tabular}{|c|c|c|c|}
\hline $\begin{array}{l}\text { (26) walaal-key } \\
\text { walaal-ka } \\
\text { walaal-'ye }\end{array}$ & $\begin{array}{l}\text { 'my brother' } \\
\text { 'your brother' } \\
\text { 'his/her brother' }\end{array}$ & $\begin{array}{l}\text { walaal-kaynu } \\
\text { walaal-kin } \\
\text { walaal-'yo }\end{array}$ & $\begin{array}{l}\text { 'our brother' } \\
\text { 'your pl. brother' } \\
\text { 'their brother' }\end{array}$ \\
\hline $\begin{array}{l}\text { igar-key } \\
\text { igar-ka } \\
\text { igar-'ye }\end{array}$ & $\begin{array}{l}\text { 'my son' } \\
\text { 'your son' } \\
\text { 'his/her son' }\end{array}$ & $\begin{array}{l}\text { igar-kaynu } \\
\text { igar-kin } \\
\text { igar-'yo }\end{array}$ & $\begin{array}{l}\text { 'our son' } \\
\text { 'your pl. son' } \\
\text { 'their son' }\end{array}$ \\
\hline $\begin{array}{l}\text { aw-key } \\
\text { aw-ka } \\
\text { aw-'ye }\end{array}$ & $\begin{array}{l}\text { 'my father' } \\
\text { 'your father' } \\
\text { 'his/her father' }\end{array}$ & $\begin{array}{l}\text { aw-kaynu } \\
\text { aw-kin } \\
\text { aw-'yo }\end{array}$ & $\begin{array}{l}\text { 'our father' } \\
\text { 'your pl. father' } \\
\text { 'their father' }\end{array}$ \\
\hline 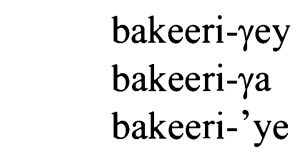 & $\begin{array}{l}\text { 'my cup' } \\
\text { 'your cup' } \\
\text { 'his/her cup' }\end{array}$ & 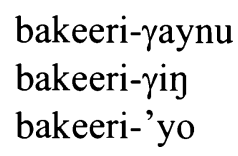 & $\begin{array}{l}\text { 'our cup' } \\
\text { 'your pl. cup' } \\
\text { 'their cup' }\end{array}$ \\
\hline $\begin{array}{l}\text { eey-key } \\
\text { eey-ka } \\
\text { eey-'ye }\end{array}$ & $\begin{array}{l}\text { 'my dog', } \\
\text { 'your dog' } \\
\text { 'his/her dog' }\end{array}$ & $\begin{array}{l}\text { eey-kayno } \\
\text { eey-kin } \\
\text { eey-'yo }\end{array}$ & $\begin{array}{l}\text { 'our dog' } \\
\text { 'your pl. dog' } \\
\text { 'their dog' }\end{array}$ \\
\hline $\begin{array}{l}\text { buug-ey } \\
\text { buug-a } \\
\text { buuk-'ye }\end{array}$ & $\begin{array}{l}\text { 'my book' } \\
\text { 'your book' } \\
\text { 'his/her book' }\end{array}$ & $\begin{array}{l}\text { buug-ayno } \\
\text { buug-in } \\
\text { buuk-'yo }\end{array}$ & $\begin{array}{l}\text { 'our book' } \\
\text { 'your pl. book' } \\
\text { 'their book' }\end{array}$ \\
\hline
\end{tabular}

Feminine possessed (singular) nouns are shown below. Note that, unlike masculine nouns, feminine nouns take different forms depending on whether the $3 \mathrm{sg}$ possessor is masculine or feminine.

\begin{tabular}{|c|c|c|c|}
\hline $\begin{array}{l}\text { (27) } \\
\text { gewer-tey } \\
\text { gewer-ta } \\
\text { gewer-tis } \\
\end{array}$ & $\begin{array}{l}\text { 'my daughter' } \\
\text { 'your daughter' } \\
\text { 'his daughter' } \\
\text { 'her daughter' }\end{array}$ & $\begin{array}{l}\text { gewer-tayno } \\
\text { gewer-tin } \\
\text { gewer-tio }\end{array}$ & $\begin{array}{l}\text { 'our daughter' } \\
\text { 'your pl. daughter' } \\
\text { 'their daughter' }\end{array}$ \\
\hline $\begin{array}{l}\text { mindi-ðey } \\
\text { mindi-ða } \\
\text { mindi-ðis } \\
\text { mindi-ðie }\end{array}$ & $\begin{array}{l}\text { 'my knife' } \\
\text { 'your knife' } \\
\text { 'his knife' } \\
\text { 'her knife' }\end{array}$ & $\begin{array}{l}\text { mindi-ðayno } \\
\text { mindi-ðin } \\
\text { mindi-ðio }\end{array}$ & $\begin{array}{l}\text { 'our knife' } \\
\text { 'your pl. knife' } \\
\text { 'their knife' }\end{array}$ \\
\hline
\end{tabular}




\begin{tabular}{|c|c|c|c|}
\hline sa?-ðey & 'my cow' & sa?-ðayno & 'our cow' \\
\hline sa?-ða & 'your cow' & sa?-ðin & 'your pl. cow' \\
\hline sa?-ðis & 'his cow' & sa?-ðio & 'their cow' \\
\hline sa?-ðie & 'her cow' & & \\
\hline hambal-ey & 'my leaf' & hambal-ayno & 'our leaf' \\
\hline hambal-a & 'your leaf' & hambal-in & 'your pl. leaf' \\
\hline hambal-is & 'his leaf' & hambal-io & 'their leaf' \\
\hline hambal-ie & 'her leaf' & & \\
\hline istaraša-ðey & 'my napkin' & istaraša-ðayno & 'our napkin' \\
\hline istaraša-ða & 'your napkin' & istaraša-ðin & 'your pl. napkin' \\
\hline istaraša-ðis & 'his napkin' & istaraša-ðio & 'their napkin' \\
\hline istaraša-ðie & 'her napkin' & & \\
\hline jeer-tey & 'my hippo' & jeer-tayno & 'our hippo' \\
\hline jeer-ta & 'your hippo' & jeer-tin & 'your pl. hippo' \\
\hline jeer-tis & 'his hippo' & jeer-tio & 'their hippo' \\
\hline jeer-tie & 'her hippo' & & \\
\hline
\end{tabular}

As mentioned in section 3.2, feminine nouns take masculine agreement when pluralized. The nouns seen above are shown here in their plural possessed forms with masculine agreement.

(28)

gewer-o-yey 'my daughters' gewer-o- $\gamma \mathrm{a}$ 'your daughters' gewer-o-'ye 'his/her daughters'

mindi-yal-key 'my knives' mindi-yal-ka 'your knives' mindi-yal-kis 'his/her knives'

\begin{tabular}{|c|c|}
\hline sa?-o-yey & 'my cows' \\
\hline 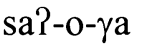 & 'your cows' \\
\hline sa?-o-’ye & 'his/her cows' \\
\hline
\end{tabular}

hambal-o-rey 'my leaves' hambal-o-ya 'your leaves' hambal-o-'ye 'his/her leaves'

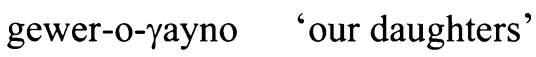

gewer-o- $\gamma$ in

gewer-o-'yo 'your pl. daughters' 'their daughters'

mindi-yal-kayno 'our knives' mindi-yal-kin 'your pl. knives' mindi-yal-'yo 'their knives' sa?-o-yayno 'our cows' sa?-o- $\gamma$ in 'your pl. cows' sa?-o-'yo 'their cows'

hambal-o-yayno 'our leaves' hambal-o-yin 'your pl. leaves' hambal-o-'yo 'their leaves' 
Like definite markers and demonstratives, the possessive markers occur at the end of the noun phrase when the noun is followed by an adjective. This is seen in the examples below.

(29)

$\begin{array}{ll}\text { sa? wiin-tey } & \text { 'my big cow' } \\ \text { geet deer-key } & \text { 'my tall tree' } \\ \text { mindi yariis-tey } & \text { 'my small knife' } \\ \text { baaka geðud-ey } & \text { 'my red box' }\end{array}$

\section{Verb Morphology.}

4.1 Derivational Morphology. This study did not reveal a robust system of verbal derivational morphology. The verbal extensions documented by Saeed (1982) are difficult to elicit from the LJM consultant and may be lexicalized in the forms that are attested. The two attested extensions, Causative and Reflexive, are discussed below.

A causative suffix $-i$ is exhibited with one verb, warab 'drink'. When the suffix is added, the meaning of the verb is 'water' (i.e., cause to drink). No other instances of this suffix are documented.
(30) ani
bio wara $\beta$-i
'I drank water'
water drink -1 sg.past
mukulal-i bio warap-ti
'the cat drank water'
cat -def water drink -3sg.fem.past
mukulal-i bio wara $\beta-\mathrm{i} \quad-\mathrm{i}$
cat $\quad$-def
water

A second verbal extension in LJM is the reflexive. Like the causative, this suffix is apparently not very productive; it was found with only three verbs in this study, and in one case the meaning of the suffix is not transparent, suggesting that the combination of the verb with the reflexive suffix is lexicalized, at least for that particular verb. Examples of the reflexive suffix are shown below. 
(31) a. Reflexive forms with transparent semantics
ani bar -oy -e
'I am teaching'
$1 \mathrm{sg}$ teach-pres-1sg
ani bar -ið -oy -e
'I am learning'
$1 \mathrm{sg}$
teach-refl-pres-1sg
ani minin dis -oy -e
'I am building a house'
$1 \mathrm{sg}$ house build-pres-1sg
ani minin dis -ið -oy -e 'I am building myself a house'
$1 \mathrm{sg}$ house build-refl-pres-1sg

b. Reflexive form with non-transparent semantics
ani gað-oy -e
'I am selling'
1 sg $\quad$ sell -pres-1sg
ani gað-ið -oy -e
'I am buying'
$1 \mathrm{sg}$
sell -refl-pres-1sg

4.2 Person marking and agreement. Verbs are marked with suffixes that indicate person and number (and, for 3sg, masculine or feminine gender). These can co-occur with an independent proclitic pronoun, or the independent pronoun can be omitted (this is, in fact, the default case; the independent pronoun is used only to emphasize the subject). For each tense/aspect/mood (to be discussed in the sections to follow), each person/number/gender is marked by a separate suffix, except that the $1 \mathrm{sg}$ verb forms are always identical to the $3 \mathrm{sg}$ masculine forms, and $2 \mathrm{sg}$ forms are always identical to $3 \mathrm{sg}$ feminine forms. This is true in other dialects as well; for example, in Central Somali, $1 \mathrm{sg}$ and $3 \mathrm{sgm}$ are identical, and $2 \mathrm{sg}$ and $3 \mathrm{sgf}$ are identical, except in a small number of irregular verbs (Saeed 1982: 23-28).

Feminine gender is indicated on the verb only when the subject is $3 \mathrm{sg}$. Tense, aspect, and mood suffixes are $t$-initial when the subject is feminine. There is likely a connection between this $-t$ and the $t$ that is observed at the beginning of feminine-agreeing noun markers, but this does not necessarily demonstrate the existence of a separate /- $t$ / feminine suffix since verbs with $3 \mathrm{sg}$ feminine subjects lack [t] in some contexts (e.g., the simple future forms to be described in section 4.3). Also, verb forms with $2 \mathrm{sg}$ and $2 \mathrm{spl}$ subjects also have $t$-initial verb suffixes 
regardless of the gender of the subject, so if there is a feminine suffix $/-t /$, there would have to be a homophonous second person suffix /-t/ despite the fact that first person and third person are not marked.

4.3 Tense. Six tenses are distinguished in LJM: past, two present tenses, and three different futures. The past, both present forms, and the simple future consist of individual verb stems inflected with a single tense suffix, while the two other future tenses involve the use of what are analyzed as auxiliary verbs.

The set of subject markers indicating past tense (Simple Past) are given below.

$\begin{array}{lllll}\text { (32) } & -\mathrm{i} & 1 \mathrm{sg} & -\mathrm{ni} & 1 \mathrm{pl} \\ -\mathrm{ti} & 2 \mathrm{sg} & - \text { teena } & 2 \mathrm{pl} \\ -\mathrm{i} & 3 \mathrm{sg} \text { masc } & \text {-eena } & 3 \mathrm{pl} \\ -\mathrm{ti} & 3 \mathrm{sg} \text { fem } & & \end{array}$

Some examples of the use of these suffixes are given below.

\begin{tabular}{|c|c|c|c|c|c|}
\hline $\begin{array}{l}\text { (33) ani } \\
\text { aði } \\
\text { usu } \\
\text { ii }\end{array}$ & $\begin{array}{l}\text { roor-i } \\
\text { roor-ti } \\
\text { roor-i } \\
\text { roor-ti }\end{array}$ & $\begin{array}{l}\text { 'I ran' } \\
\text { 'you ran' } \\
\text { 'he ran' } \\
\text { 'she ran' }\end{array}$ & $\begin{array}{l}\text { unu } \\
\text { isin } \\
\text { iyo }\end{array}$ & $\begin{array}{l}\text { roor-ni } \\
\text { roor-teena } \\
\text { roor-eena }\end{array}$ & $\begin{array}{l}\text { 'we ran' } \\
\text { 'you pl. ran' } \\
\text { 'they ran' }\end{array}$ \\
\hline $\begin{array}{l}\text { ani } \\
\text { aði } \\
\text { usu } \\
\text { ii }\end{array}$ & $\begin{array}{l}\text { šageey-i } \\
\text { šageey-ti } \\
\text { šageey-i } \\
\text { šageey-ti }\end{array}$ & $\begin{array}{l}\text { 'I worked' } \\
\text { 'you worked' } \\
\text { 'he worked' } \\
\text { 'she worked' }\end{array}$ & $\begin{array}{l}\text { unu } \\
\text { isin } \\
\text { iyo }\end{array}$ & $\begin{array}{l}\text { šageey-ni } \\
\text { šageey-teena } \\
\text { šageey-eena }\end{array}$ & $\begin{array}{l}\text { 'we worked' } \\
\text { 'you pl. worked' } \\
\text { 'they worked' }\end{array}$ \\
\hline $\begin{array}{l}\text { ani } \\
\text { aði } \\
\text { usu } \\
\text { ii }\end{array}$ & $\begin{array}{l}\text { dow-i } \\
\text { dow-ti } \\
\text { dow-i } \\
\text { dow-ti }\end{array}$ & $\begin{array}{l}\text { 'I hit' } \\
\text { 'you hit' } \\
\text { 'he hit' } \\
\text { 'she hit' }\end{array}$ & $\begin{array}{l}\text { unu } \\
\text { isin } \\
\text { iyo }\end{array}$ & $\begin{array}{l}\text { dow-ni } \\
\text { dow-teena } \\
\text { dow-eena }\end{array}$ & $\begin{array}{l}\text { 'we hit' } \\
\text { 'you pl. hit' } \\
\text { 'they hit' }\end{array}$ \\
\hline $\begin{array}{l}\text { ani } \\
\text { aði } \\
\text { usu } \\
\text { ii }\end{array}$ & $\begin{array}{l}\text { aam-i } \\
\text { aan-ti } \\
\text { aam-i } \\
\text { aan-ti }\end{array}$ & $\begin{array}{l}\text { 'I ate' } \\
\text { 'you ate' } \\
\text { 'he ate' } \\
\text { 'she ate' }\end{array}$ & $\begin{array}{l}\text { unu } \\
\text { isin } \\
\text { iyo }\end{array}$ & $\begin{array}{l}\text { aay-ni } \\
\text { aan-teena } \\
\text { aam-eena }\end{array}$ & $\begin{array}{l}\text { 'we ate' } \\
\text { 'you pl. ate' } \\
\text { 'they ate' }\end{array}$ \\
\hline
\end{tabular}


The category that I will refer to as Simple Present $\mathrm{A}$ is used to form the present tense of active verbs. It is apparently not very commonly used, since the consultant first volunteers a different form (the Present Progressive) when prompted to give a present form, even when the English prompt is stated in a generic future form rather than progressive (e.g., 'I eat' instead of 'I am eating'). The Simple Present A was first found on auxiliary verbs in constructions such as the Generic Future and Future Potential, and was never elicited with other, lexical verbs. The set of suffixes that mark Simple Present A is given below.

$\begin{array}{lllll}\text { (34) } & \text {-e } & 1 \mathrm{sg} & \text {-ne } & 1 \mathrm{pl} \\ \text {-te } & 2 \mathrm{sg} & \text {-teena } & 2 \mathrm{pl} \\ \text {-e } & 3 \mathrm{sg} \text { masc } & \text {-eena } & 3 \mathrm{pl} \\ \text {-te } & 3 \mathrm{sg} \text { fem } & & \end{array}$

Some examples of Simple Present A verbs are shown below.
(35)

\begin{tabular}{|c|c|c|c|c|}
\hline $\mathrm{ra} \beta-\mathrm{e}$ & 'I will' & unu & rab-ne & 'we will' \\
\hline rap-te & 'you will' & isin & rap-teena & 'you pl. will' \\
\hline raß-e & 'he will' & iyo & ra $\beta$-eena & 'they will' \\
\hline rap-te & 'she will' & & & \\
\hline & 'I think' & & $m$ & forms \\
\hline muð-e & 'he thinks' & & pted fo & $r$ this verb) \\
\hline
\end{tabular}

A different simple present form is used with stative verbs. I refer to this as Simple Present B. The subject agreement suffixes used in Simple Present B are shown below.
(36) -ya $1 \mathrm{sg}$
-na $\quad 1 \mathrm{pl}$
-ta $2 \mathrm{sg}$
-tena $2 \mathrm{pl}$
-ya 3 sg masc
-yena $3 \mathrm{pl}$
-ta $3 \mathrm{sg}$ fem

Some examples of stative verbs in Simple Present B are given below. 


\begin{tabular}{|c|c|c|c|c|}
\hline $\begin{array}{l}\text { (37) ani } \\
\text { aði } \\
\text { usu } \\
\text { ii }\end{array}$ & $\begin{array}{l}\text { farahsiñ-ya } \\
\text { farahsin-ta } \\
\text { farahsiñ-ya } \\
\text { farahsin-ta }\end{array}$ & $\begin{array}{l}\text { 'I am happy' } \\
\text { 'you are happy' } \\
\text { 'he is happy' } \\
\text { 'she is happy' }\end{array}$ & $\begin{array}{l}\text { unu farahsin-na } \\
\text { isin farahsin-tena } \\
\text { iyo farahsin-yena }\end{array}$ & $\begin{array}{l}\text { 'we are happy' } \\
\text { 'you are happy' } \\
\text { 'they are happy' }\end{array}$ \\
\hline $\begin{array}{l}\text { ani } \\
\text { aði } \\
\text { usu } \\
\text { ii }\end{array}$ & $\begin{array}{l}\text { deer-ya } \\
\text { deer-ta } \\
\text { deer-ya } \\
\text { deer-ta }\end{array}$ & $\begin{array}{l}\text { 'I am tall' } \\
\text { 'you are tall' } \\
\text { 'he is tall' } \\
\text { 'she is tall' }\end{array}$ & $\begin{array}{l}\text { unu deer-na } \\
\text { isin deer-tena } \\
\text { iyo deer-yena }\end{array}$ & $\begin{array}{l}\text { 'we are tall' } \\
\text { 'you pl. are tall' } \\
\text { 'they are tall' }\end{array}$ \\
\hline $\begin{array}{l}\text { ani } \\
\text { aði } \\
\text { usu } \\
\text { ii }\end{array}$ & $\begin{array}{l}\text { buuriñ-ya } \\
\text { buurin-ta } \\
\text { buuriñ-ya } \\
\text { buurin-ta }\end{array}$ & $\begin{array}{l}\text { 'I am fat' } \\
\text { 'you are fat' } \\
\text { 'he is fat' } \\
\text { 'she is fat' }\end{array}$ & $\begin{array}{l}\text { unu buurin-na } \\
\text { isin buurin-tena } \\
\text { iyo buuriñ-yena }\end{array}$ & $\begin{array}{l}\text { 'we are fat' } \\
\text { 'you pl. are fat' } \\
\text { 'they are fat' }\end{array}$ \\
\hline $\begin{array}{l}\text { ani } \\
\text { aði } \\
\text { usu } \\
\text { ii }\end{array}$ & $\begin{array}{l}\text { mooñ-ya } \\
\text { moon-ta } \\
\text { mooñ-ya } \\
\text { moon-ta }\end{array}$ & $\begin{array}{l}\text { 'I am big' } \\
\text { 'you are big' } \\
\text { 'he is big' } \\
\text { 'she is big', }\end{array}$ & $\begin{array}{l}\text { unu moon-na } \\
\text { isin moon-tena } \\
\text { iyo mooñ-yena }\end{array}$ & $\begin{array}{l}\text { 'we are big' } \\
\text { 'you pl. are big' } \\
\text { 'they are big' }\end{array}$ \\
\hline
\end{tabular}

Another tense, the Generic Future, indicates general future action with no specific timeframe. The Generic Future verb consists of an uninflected form of the main verb followed by a form of the auxiliary verb $/$ don $/{ }^{13}$ with a subject agreement suffix taken from the set below. Note that this set of suffixes is very similar to those used with the Simple Present B (stative) forms discussed above, but the suffixes are not identical.

${ }^{13}$ The underlying form of this verb, with respect to the final nasal, is not fully determined by the data since it occurs only in pre-consonantal environments. As was seen above, the most common final nasal in nouns is $/ \mathrm{m} /$, so this could be extended to argue in favor of $/ \mathrm{dom} /$ rather than /don/. However, we have no clear evidence for a similar pattern in verbs (only two nasal-final lexical verbs were observed, and although both happen to end in $/ \mathrm{m} /$, this sample size seems too small to generalize). Furthermore, the verb never surfaces with the form [dom], whereas it does surface as [don] when it occurs with $t$-initial suffixes. Although this fact is consistent with both /dom/ and /don/, I will assume /don/ for the sake of minimizing abstractness. 
(38)

$$
\begin{array}{ll}
\text {-ya } & 1 \mathrm{sg} \\
\text {-te } & 2 \text { sg } \\
\text {-ya } & 3 \text { sg masc } \\
\text {-te } & 3 \text { sg fem }
\end{array}
$$

$\begin{array}{ll}\text {-ne } & 1 \mathrm{pl} \\ \text {-teena } & 2 \mathrm{pl} \\ \text {-yeena } & 3 \mathrm{pl}\end{array}$

Examples of Generic Future forms are given below.

$\begin{array}{llll}\text { (39) ani } & \text { roor } & \text { doñ-ya } & \text { 'I will run' } \\ \text { aði } & \text { roor } & \text { don-te } & \text { 'you will run' } \\ \text { usu } & \text { roor } & \text { doñ-ya } & \text { 'he will run' } \\ \text { ii } & \text { roor } & \text { don-te } & \text { 'she will run' } \\ \text { unu } & \text { roor } & \text { don-ne } & \text { 'we will run' } \\ \text { isin } & \text { roor } & \text { don-teena } & \text { 'you pl. will run' } \\ \text { iyo } & \text { roor } & \text { doñ-yeena } & \text { 'they will run' }\end{array}$

ani nook doñ-ya 'I will be tired'

aði nook don-te 'you will be tired'

usu nook doñ-ya 'he will be tired'

ii nook don-te 'she will be tired'

unu nook don-ne 'we will be tired'

isin nook don-teena 'you pl. will be tired'

iyo nook doñ-yeena 'they will be tired'

ani šageey doñ-ya 'I will work'

aði šageey don-te 'you will work'

usu šageey doñ-ya 'he will work'

ii šageey don-te 'she will work'

unu šageey don-ne 'we will work'

isin šageey don-teena 'you pl. will work'

iyo šageey doñ-yeena 'they will work'

ani hees doñ-ya 'I will sing'

aði hees don-te 'you will sing'

usu hees doñ-ya 'he will sing'

ii hees don-te 'she will sing'

unu hees don-ne 'we will sing'

isin hees don-teena 'you pl. will sing'

iyo hees doñ-yeena 'they will sing' 
The Immediate Future is a simple future tense that indicates action that will take place very soon, within even a few seconds. The meaning seems to correspond to that of the English construction 'about to do X'. Immediate Future forms consist of the verb followed by a subject agreement suffix from the set shown below.

$$
\begin{array}{lll}
\text { (40) } & -\mathrm{e} & 1 \mathrm{sg} \\
\text {-ase } & 2 \mathrm{sg} \\
-\mathrm{e} & 3 \mathrm{sg} \text { masc } \\
\text {-ase } & 3 \mathrm{sg} \text { fem }
\end{array}
$$

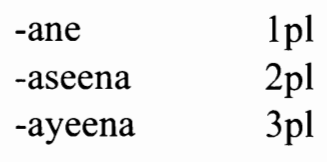

\begin{tabular}{|c|c|c|c|}
\hline gor-e & 'I will write' & unu gor-ane & 'we will write' \\
\hline gor-ase & 'you will write' & isin gor-aseena & 'you pl. will write \\
\hline gor-e & 'he will write' & iyo gor-ayeena & 'they will write' \\
\hline gor-ase & 'she will write' & & \\
\hline
\end{tabular}

Some examples of Immediate Future verbs are shown below.

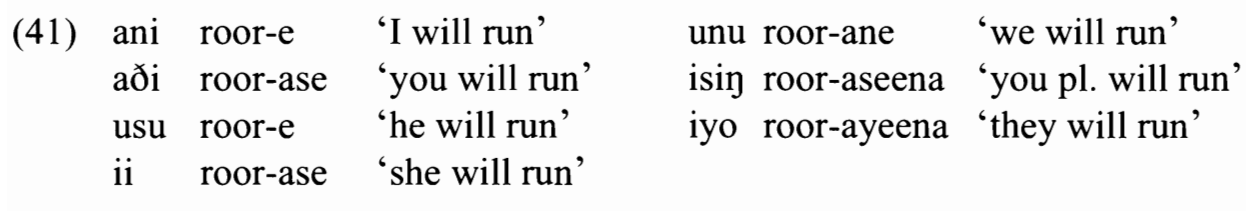

$\begin{array}{llll}\text { ani } & \text { kooy-e } & \text { 'I will come' } & \text { unu kooy-ane 'we will come' } \\ \text { aði } & \text { kooy-ase } & \text { 'you will come' } & \text { isin kooy-aseena 'you pl. will come' } \\ \text { usu kooy-e } & \text { 'he will come' } & \text { iyo kooy-ayeena 'they will come' } \\ \text { ii } & \text { kooy-ase } & \text { 'she will come' } & \end{array}$

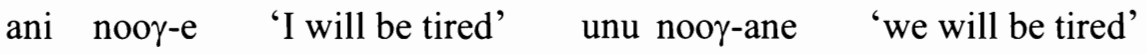
aði nooy-ase 'you will be tired' isin nooy-aseena 'you pl. will be tired'

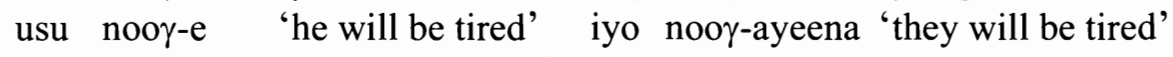 ii nooy-ase 'she will be tired'

The Near Future form of a verb indicates action that will happen shortly, perhaps within the next 15 minutes to an hour, according to the consultant. Near Future forms consist of the main verb in its Generic Potential form (the Generic 
Potential will be described in section 4.4) followed by the Simple Present A form of the auxiliary verb /rab/. Examples are shown below.

\begin{tabular}{|c|c|c|c|c|}
\hline \multirow[t]{7}{*}{$(42)$} & ani & roor-o & ra $\beta$-e & 'I will run' \\
\hline & aði & roor-to & rap-te & 'you will run' \\
\hline & usu & roor-o & $\mathrm{ra} \beta-\mathrm{e}$ & 'he will run' \\
\hline & ii & roor-to & rap-te & 'she will run' \\
\hline & unu & roor-no & rab-ne & 'we will run' \\
\hline & isin & roor-tona & rap-teena & 'you pl. will run' \\
\hline & iyo & roor-ona & ra $\beta$-eena & 'they will run' \\
\hline & ani & umboh-o & $\mathrm{ra} \beta-\mathrm{e}$ & 'I will go' \\
\hline & aði & umboh-to & rap-te & 'you will go' \\
\hline & usu & umboh-o & $\mathrm{ra} \beta-\mathrm{e}$ & 'he will go' \\
\hline & ii & umboh-to & rap-te & 'she will go' \\
\hline & unu & umbah-no & rab-ne & 'we will go' \\
\hline & isin & umbah-tona & rap-teena & 'you pl. will go' \\
\hline & iyo & umbah-ona & ra $\beta$-eena & 'they will go' \\
\hline & ani & šageey-o & $\mathrm{ra} \beta-\mathrm{e}$ & 'I will work' \\
\hline & aði & šageey-to & rap-te & 'you will work' \\
\hline & usu & šageey-o & raß-e & 'he will work' \\
\hline & ii & šageey-to & rap-te & 'she will work' \\
\hline & unu & šageey-no & rab-ne & 'we will work' \\
\hline & isin & šageey-tona & rap-teena & 'you pl. will work' \\
\hline & iyo & šageey-ona & $\mathrm{ra} \beta$-eena & 'they will work' \\
\hline & ani & gor-o & $\mathrm{ra} \beta-\mathrm{e}$ & 'I will write' \\
\hline & aði & gor-to & rap-te & 'you will write' \\
\hline & usu & gor-o & $\mathrm{ra} \beta-\mathrm{e}$ & 'he will write' \\
\hline & ii & gor-to & rap-te & 'she will write' \\
\hline & unu & gor-no & rab-ne & 'we will write' \\
\hline & isin & gor-tona & rap-teena & 'you pl. will write' \\
\hline & iyo & gor-ona & ra $\beta$-eena & 'they will write' \\
\hline
\end{tabular}

Two primary moods are distinguished aside from the unmarked, default (indicative) mood: Imperative and Potential. Each of these moods is discussed below. 
Imperative is unmarked when the subject is singular, and is marked by $-a$ when the subject is plural, as seen in the examples below.

(43)

$\begin{array}{ll}\text { aði roor } & \text { 'run!' } \\ \text { isin roor-a } & \text { 'run! pl.' }\end{array}$

bah

bah-a

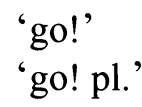

aan

aam-a

gor

gor-a 'eat!'

'eat! pl.'

'write!'

'write! pl.'

Potential mood is generally used to indicate actions that may be taking place in the present or future: 'maybe $\mathrm{X}$ ' or ' $\mathrm{I}$ think that $\mathrm{X}$ ' or actions that did not take place in the past (past conditional forms of the type 'I would have X, but...'). Potential mood is marked by ina, which occurs before the verb and is indicated as a prefix here but may be a complementizer that introduces clauses containing potential verbs. There are two types of Potential verbs: Future Potential and Generic Potential.

Future Potential verbs consist of a main verb preceded by ina and inflected with a suffix from the set in (44), followed by muð-e, which is the 1sg Simple Present A form of the verb meaning 'to think'.
(44) -aw $1 \mathrm{sg}$
-aso $2 \mathrm{sg}$
-aano
$1 \mathrm{pl}$
-aw $3 \mathrm{sg}$ masc
-aasona
$2 \mathrm{pl}$
-aso $3 \mathrm{sg}$ fem
-aayona
$3 \mathrm{pl}$

Examples of Future Potential verbs are shown here. Note that these forms are not complete utterances: in actual use, each of these forms would be followed by muð-e.
(45) ani ina-[?]aam-aw
'I might eat'
aði ina-[?]aam-aso
'you might eat'
usu ina-[?]aam-aw
'he might eat'
ii ina-[?]aam-aso
'she might eat'
unu ina-[?]aam-aano
'we might eat'
isin ina-[?]aam-aasoona
'you pl. might eat'
iyo ina-[?]aam-aayoona
'they might eat' 


\begin{tabular}{|c|c|c|}
\hline ani & ina-hees-aw & 'I might sing' \\
\hline aði & ina-hees-aso & 'you might sing' \\
\hline usu & ina-hees-aw & 'he might sing' \\
\hline ii & ina-hees-aso & 'she might sing' \\
\hline unu & ina-hees-aano & 'we might sing' \\
\hline isin & ina-hees-aasoona & 'you pl. might sing' \\
\hline iyo & ina-hees-aayoona & 'they might sing' \\
\hline ani & ina-kooy-aw & 'I might come' \\
\hline aði & ina-kooy-aso & 'you might come' \\
\hline usu & ina-kooy-aw & 'he might come' \\
\hline ii & ina-kooy-aso & 'she might come' \\
\hline unu & ina-kooy-aano & 'we might come' \\
\hline isin & ina-kooy-aasoona & 'you pl. might come' \\
\hline yo & ina-kooy-aayoona & 'they might come' \\
\hline hi & ina-dam-aw & 'I might drink' \\
\hline Øi & ina-dam-aso & 'you might drink' \\
\hline usu & ina-dam-aw & 'he might drink' \\
\hline ii & ina-dam-aso & 'she might drink' \\
\hline unu & ina-dam-aano & 'we might drink' \\
\hline in & ina-dam-aasoona & 'you pl. might drink' \\
\hline O & ina-dam-aayoona & 'they might drink' \\
\hline
\end{tabular}

Generic Potential forms indicate action that may be taking place currently or may have happened in the past. Present forms consist of the main verb preceded by ina, inflected using one of the suffixes in (46), and obligatorily followed by lakayaawe 'maybe'.
(46) $\quad-0 \quad 1 s g$
-no $\quad 1 \mathrm{pl}$
-to $2 \mathrm{sg}$
-tona $2 \mathrm{pl}$
-o $\quad 3 \mathrm{sg}$ masc
-ona
$3 \mathrm{pl}$
-to $3 \mathrm{sg}$ fem

Some examples of present tense Generic Potential forms are shown below. Note that in order for these forms to become coherent utterances, they should each be followed by lakayaawe. 

(47) ani ina-kooy-o
aði ina-kooy-to
'I might be coming'
usu ina-kooy-o
'you might be coming'
ii ina-kooy-to
'he might be coming'
unu ina-kooy-no
'she might be coming'
isin ina-kooy-tona
'we might be coming'
iyo ina-kooy-ona
'you pl. might be coming'
'they might be coming'
ani ina-hees-o
aði ina-hees-to
'I might be singing'
usu ina-hees-o
'you might be singing'
ii ina-hees-to
'he might be singing'
unu ina-hees-no
'she might be singing'
isin ina-hees-tona
'we might be singing'
'you pl. might be singing'
iyo ina-hees-ona
'they might be singing'

Another context for the use of the Generic Potential is in conditional forms, which are apparently only used in the past tense. A past conditional form consists of the Generic Potential form of the main verb (without ina) followed by the Past Progressive form (see section 4.5) of $/ \mathrm{rap} /$, which is the same auxiliary verb stem that is used in the Near Future tense described in section 4.3. Examples are shown below.
(48)
$\begin{array}{lll}\text { ani } & \text { roor-o } & \text { ra } \beta-a y-i \\ \text { aði } & \text { roor-to } & \text { ra } \beta \text {-ay-ti } \\ \text { usu } & \text { roor-o } & \text { ra } \beta \text {-ay-i } \\ \text { ii } & \text { roor-to } & \text { ra } \beta \text {-ay-ti } \\ \text { unu } & \text { roor-no } & \text { ra } \beta \text {-ay-ni } \\ \text { isin } & \text { roor-tona } & \text { ra } \beta \text {-ay-teena } \\ \text { iyo } & \text { roor-ona } & \text { ra } \beta \text {-ay-eena }\end{array}$
'I would have run'
'you would have run'
'he would have run'
'she would have run'
'we would have run'
'you pl. would have run'
'they would have run'
$\begin{array}{lll}\text { ani } & \text { umbah-o } & \text { ra } \beta \text {-ay-i } \\ \text { aði } & \text { umbah-to } & \text { ra } \beta \text {-ay-ti } \\ \text { usu } & \text { umbah-o } & \text { ra } \beta \text {-ay-i } \\ \text { ii } & \text { umbah-to } & \text { ra } \beta \text {-ay-ti } \\ \text { unu } & \text { umbah-no } & \text { ra } \beta \text {-ay-ni } \\ \text { isin } & \text { umbah-tona } & \text { ra } \beta \text {-ay-teena } \\ \text { iyo } & \text { umbah-ona } & \text { ra } \beta \text {-ay-eena }\end{array}$
'I would have gone'
'you would have run'
'he would have run'
'she would have run'
'we would have run'
'you pl. would have run'
'they would have run' 
4.5 Aspect. Two aspectual categories are marked in LJM: Progressive (present and past), and Habitual (past only). These aspects are described below.

The Present Progressive aspect is marked with the suffix -oy. This suffix occurs before the subject agreement suffixes, which are taken from the set of Simple Present A suffixes discussed in section 4.3.

(49)

\author{
'I am running' \\ 'you are running' \\ 'he is running' \\ 'she is running' \\ 'we are running' \\ 'you pl. are running' \\ 'they are running'
}

ani aam-oy-e
aði aam-oy-te
usu aam-oy-e
ii aam-oy-te
unu aam-oy-ne
isin aam-oy-teena
iyo aam-oy-eena

'I am eating'

'you are eating'

'he is eating'

'she is eating'

'we are eating'

'you pl. are eating'

'they are eating'
ani siy-oy-e
'I am giving'
aði siy-oy-te
'you are giving'
usu siy-oy-e
'he is giving'
ii siy-oy-te
'she is giving'
unu siy-oy-ne
'we are giving'
isin siy-oy-teena
'you pl. are giving'
iyo siy-oy-eena
'they are giving' 
The Past Progressive is marked by the suffix -ay, which is followed by a subject marker from the same set as used with the simple Past tense discussed in section 4.3. Thus, the Past Progressive is transparently composed of affixes marking progressive aspect and past tense (in that order).

$(50)$

$\begin{array}{ll}\text { ani } & \text { roor-ay-i } \\ \text { aoi } & \text { roor-ay-ti } \\ \text { usu } & \text { roor-ay-i } \\ \text { ii } & \text { roor-ay-ti } \\ \text { unu } & \text { roor-ay-ni } \\ \text { isin } & \text { roor-ay-teena } \\ \text { iyo } & \text { roor-ay-eena }\end{array}$

$\begin{array}{ll}\text { ani } & \text { šageey-ay-i } \\ \text { ađi } & \text { šageey-ay-ti } \\ \text { usu } & \text { šageey-ay-i } \\ \text { ii } & \text { šageey-ay-ti } \\ \text { unu } & \text { šageey-ay-ni } \\ \text { isin } & \text { šageey-ay-teena } \\ \text { iyo } & \text { šageey-ay-eena }\end{array}$

ani luyooy-ay-i

aði luyooy-ay-ti

usu luyooy-ay-i

ii luyooy-ay-ti

unu luyooy-ay-ni

isin luyooy-ay-teena

iyo luyooy-ay-eena
'I was running'

'you were running'

'he was running'

'she was running'

'we were running'

'you pl. were running'

'they were running'

'I was working'

'you were working'

'he was working'

'she was working'

'we were working'

'you pl were working'

'they were working'

'I was walking'

'you were walking'

'he was walking'

'she was walking'

'we were walking'

'you pl. were walking'

'they were walking'

ani gawoosið-ay-i 'I was bathing'

aði gawoosið-ay-ti 'you were bathing'

usu gawoosið-ay-i 'he was bathing'

ii gawoosið-ay-ti 'she was bathing'

unu gawoosið-ay-ni 'we were bathing'

isin gawoosið-ay-teena 'you pl. were bathing'

iyo gawoosið-ay-eena 'they were bathing' 
formed by using the infinitive (unmarked) form of the main verb followed by the

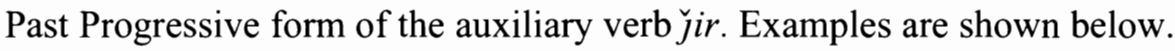

\begin{tabular}{|c|c|c|c|}
\hline (51) ani & roor & jir-i & 'I used to run' \\
\hline aði & roor & jir-ti & 'you used to run' \\
\hline usu & roor & jir-i & 'he used to run' \\
\hline ii & roor & jir-ti & 'she used to run' \\
\hline unu & roor & jir-ni & 'we used to run' \\
\hline isin & roor & jir-teena & 'you pl. used to run' \\
\hline iyo & roor & jir-eena & 'they used to run' \\
\hline ani & šagey & ǰir-i & 'I used to work' \\
\hline aði & šagey & jir-ti & 'you used to work' \\
\hline usu & šagey & jir-i & 'he used to work' \\
\hline ii & šagey & jir-ti & 'she used to work' \\
\hline unu & šagey & jir-ni & 'we used to work' \\
\hline isin & šagey & jir-teena & 'you pl. used to work' \\
\hline iyo & šagey & jir-eena & 'they used to work' \\
\hline ani & lugoy & jir-i & 'I used to walk' \\
\hline aði & lugoy & jir-ti & 'you used to walk' \\
\hline usu & lugoy & jir-i & 'he used to walk' \\
\hline ii & lugoy & jir-ti & 'she used to walk' \\
\hline unu & lugoy & jir-ni & 'we used to walk' \\
\hline isin & lugoy & jir-teena & 'you pl. used to walk' \\
\hline iyo & lugoy & jir-eena & 'they used to walk' \\
\hline ani & aañ & ǰir-i & 'I used to eat' \\
\hline aði & aañ & jir-ti & 'you used to eat' \\
\hline iyo & aañ & jir-eena & 'they used to eat' \\
\hline ii & aañ & yir-ti & 'she used to eat' \\
\hline un & aañ & y̆ir-ni & 'we used to eat' \\
\hline isin & aañ & ǰir-teena & 'you pl. used to eat' \\
\hline usu & aañ & jir-i & 'he used to eat' \\
\hline
\end{tabular}

4.6 Negative. Each of the verb forms discussed above in sections 4.3-4.5 can be negated. In many cases, negation is marked by either or both of the following: a $m a$ - prefix and an $-o$ suffix that takes the place of one of the subject agreement 
suffix vowels. This situation may be a bit more complex than in the related Central Somali dialect described by Saeed; only a general preverbal negative particle $m$ a and a negative imperative particle $ə \eta$ are mentioned for that dialect (1982: 22) along with some tone changes (1982: 23). There is no mention of a correspondent to LJM - $o$; this may relate to the general reduction of many vowels (especially final vowels) in Central Somali to [ə].

In this section, I present examples of negative forms corresponding to each of the verb forms from sections 4.3-4.5. The negative verb forms are presented according to the way in which they are formed, with the most basic negative forms given first, followed by more complex forms. Since potential verbs are negated using only a single prefix, these are presented first.

Potential verbs are made negative by prefixing $m a$ - to the verb and using the same set of person markers as in the affirmative. Examples are shown below.

a. Future Potential Negative

ani ina-ma-hees-aw

muð-e

muð-e

muð-e

muð-e

muð-e

muð-e

muð-e
'I might not sing'

(lit. 'I think I won't sing')

'you might not sing'

'he might not sing'

'she might not sing'

'we might not sing'

'you pl. might not sing'

'they might not sing'

b. Generic Potential Negative

$\begin{array}{llll}\text { ani } & \text { ina-ma-hees-o } & \text { lakayaawe 'I might not be singing', } \\ \text { usu ina-ma-hees-o } & \begin{array}{l}\text { lakayaawe 'he might not be singing', } \\ \text { ii ina-ma-hees-to }\end{array} & \text { lakayaawe 'she might not be singing, } \\ \text { unu ina-ma-hees-no } & \text { lakayaawe 'we might not be singing', } \\ \text { aði ina-ma-hees-to } & \text { lakayaawe 'you might not be singing, } \\ \text { isin ina-ma-hees-tona } & \text { lakayaawe 'you pl. might not be singing', } \\ \text { iyo ina-ma-hees-ona } & \text { lakayaawe 'they might not be singing, }\end{array}$

Several other types of verbs form plurals by prefixing $m a$ - and using the same set of subject agreement suffixes as in the affirmative except that the first vowel of each suffix is changed to [o]. As seen below, this happens in the Simple Present A (and therefore also in the Near Future, whose auxiliary verb is in the 
Simple Present A), Simple Present B (stative), Generic Future, and Present Progressive (which uses the same subject agreement suffixes as the Generic Future).

a. Simple Present A Negative ani ma-raß-o 'I will not' aði ma-rap-to 'you will not' unu ma-rab-no 'we will not' usu ma-raß-o 'he will not' ii ma-rap-to 'she will not' isin ma-rap-toona 'you pl. will not' iyo ma-raß-oona 'they will not'

b. Near Future Negative

$\begin{array}{llll}\text { ani } & \text { roor-o } & \text { ma-raß-o } & \text { 'I will not run' } \\ \text { aði } & \text { roor-to } & \text { ma-rap-to } & \text { 'you will not run' } \\ \text { usu } & \text { roor-o } & \text { ma-raß-o } & \text { 'he will not run' } \\ \text { ii } & \text { roor-to } & \text { ma-rap-to } & \text { 'she will not run' } \\ \text { unu } & \text { roor-no } & \text { ma-rab-no } & \text { 'we will not run' } \\ \text { isin } & \text { roor-tona } & \text { ma-rap-toona } & \text { 'you pl. will not run' } \\ \text { iyo } & \text { roor-ona } & \text { ma-raß-oona } & \text { 'they will not run' }\end{array}$

c. Simple Present B Negative ani ma-deer-yo

'I am not tall'

aði ma-deer-to

'you are not tall'

usu ma-deer-yo

'he is not tall'

ii ma-deer-to

'she is not tall'

unu ma-deer-no

'we are not tall'

isin ma-deer-tona

'you pl. are not tall'

iyo ma-deer-yona

'they are not tall'

d. Generic Future Negative

ani ma-roor doñ-yo

aði ma-roor don-to

'I will not run'

usu ma-roor doñ-yo

'you will not run'

ii ma-roor don-to

'he will not run'

'she will not run'

unu ma-roor don-no

'we will not run'

isin ma-roor don-toona

'you pl. will not run'

iyo ma-roor doñ-yoona

'they will not run' 
e. Present Progressive Negative

$\begin{array}{lll}\text { ani } & \text { ma-roor-oy-o } & \text { 'I am not running' } \\ \text { aði } & \text { ma-roor-oy-to } & \text { 'you are not running' } \\ \text { usu } & \text { ma-roor-oy-o } & \text { 'he is not running' } \\ \text { ii } & \text { ma-roor-oy-to } & \text { 'she is not running' } \\ \text { unu } & \text { ma-roor-oy-no } & \text { 'we are not running' } \\ \text { isin } & \text { ma-roor-oy-toona } & \text { 'you pl. are not running', } \\ \text { iyo ma-roor-oy-oona } & \text { 'they are not running' }\end{array}$

Three verb forms have plurals with a $m a$ - prefix and -ne suffix: Simple Past, Past Progressive, and Past Habitual. There is no person marking on these Negative forms, but the subject pronoun is still able to be omitted. When there is no overt subject marker, the verb form is ambiguous and the intended subject must be recovered from context. In Central Somali as well, Simple Past Negatives have only a single form, which has a -na suffix (Saeed 1982: 23), but unlike in LJM, Past Habitual forms in Central Somali use the same set of person/number/gender suffixes as in the affirmative rather than using -nə. Examples of LJM Past Negative forms are shown below.

(54) a. Past Negative

$\begin{array}{lll}\text { ani } & \text { ma-roor-ne } & \text { 'I didn't run' } \\ \text { aði ma-roor-ne } & \text { 'you didn't run' } \\ \text { usu ma-roor-ne } & \text { 'he didn't run' } \\ \text { ii } & \text { ma-roor-ne } & \text { 'she didn't run' } \\ \text { unu ma-roor-ne } & \text { 'we didn't run' } \\ \text { isin ma-roor-ne } & \text { 'you pl. didn't run' } \\ \text { iyo ma-roor-ne } & \text { 'they didn't run' }\end{array}$

b. Past Progressive Negative

$\begin{array}{lll}\text { ani ma-roor-ay-ne } & \text { 'I was not running' } \\ \text { aði ma-roor-ay-ne } & \text { 'you were not running' } \\ \text { usu ma-roor-ay-ne } & \text { 'he was not running', } \\ \text { ii ma-roor-ay-ne } & \text { 'she was not running', } \\ \text { unu ma-roor-ay-ne } & \text { 'we were not running, } \\ \text { isin ma-roor-ay-ne } & \text { 'you pl. were not running' } \\ \text { iyo ma-roor-ay-ne } & \text { 'they were not running' }\end{array}$


c. Past Habitual Negative

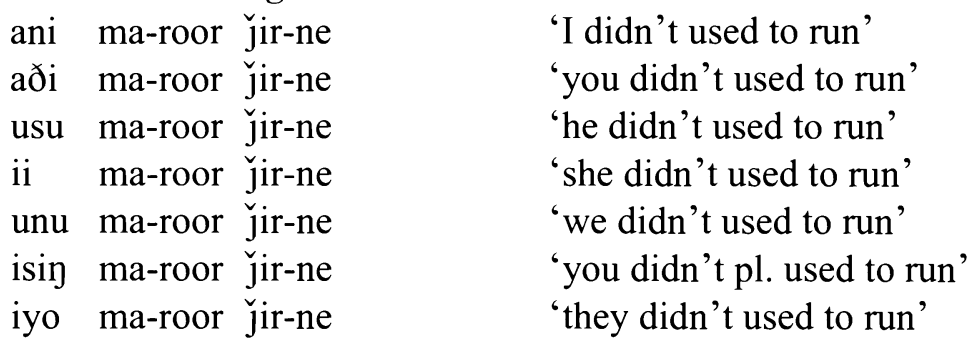

The Immediate Future Negative is formed by prefixing $m a$ - to the verb and by changing the subject agreement suffixes. For the $2 \mathrm{sg}, 3 \mathrm{sg}$ feminine, and all plural subjects, the second vowel of the suffix changes to [o]. For $1 \mathrm{sg}$ and $3 \mathrm{sg}$ masculine, the negative suffix is $-a w$, which is not directly related to the corresponding affirmative suffix, $-e$, though it is not difficult to imagine that historically the negative suffix had the form -eo, which could have undergone some sound changes to surface in the modern language as [aw]. Central Somali has -aw for the 1sg and 3sgm here as well (Saeed 1982: 24); apart from the Simple Past Negative mentioned above, this is apparently the only segmental person/number/gender suffix change that occurs in the negative form for any tense/aspect in Central Somali. Immediate Future Negative forms in LJM are shown below.

\section{(55) Immediate Future Negative}

$\begin{array}{ll}\text { ani ma-roor-aw } & \text { 'I will not run' } \\ \text { aði ma-roor-aso } & \text { 'you will not run' } \\ \text { usu ma-roor-aw } & \text { 'he will not run' } \\ \text { ii ma-roor-aso } & \text { 'she will not run' } \\ \text { unu ma-roor-ano } & \text { 'we will not run' } \\ \text { isin ma-roor-asoona } & \text { 'you pl. will not run' } \\ \text { iyo ma-roor-ayoona } & \text { 'they will not run' }\end{array}$

The one verb form whose Negative form does not fit any of the descriptions above is the Imperative. The Imperative Negative is formed by prefixing $a \eta$ to the Imperative verb and adding a suffix -to or -tona (for singular or plural subjects, respectively). Note that the negative suffixes do not relate transparently to the corresponding affirmative suffixes, $-\varnothing$ (for a singular subject) and $-a$ (for a plural subject). Imperative Negative examples are given below. 
(56) Imperative Negative

$\begin{array}{ll}\text { ay-roor-to } & \text { 'don't run!' } \\ \text { ay-roor-tona } & \text { 'don't run! pl.' }\end{array}$

An issue that arises in the analysis of Negative verb forms is in identifying what part(s) of a complex verb the negation applies to. In the case of simple verbs with no auxiliary verb, such as the Present Progressive, the negative prefix occurs immediately before the verb stem, and the negative 'suffix' is manifested by changing a vowel of the subject agreement suffix. In some verb forms, such as the Near Future, the negative markers apply only to the auxiliary verb, whereas in other complex forms, such as the Generic Future, the negative prefix occurs before the main verb stem while the suffix vowel change applies to suffixes attached to the auxiliary verb. It may be the case that in cases where a negative prefix and suffix 'surround' both the main and auxiliary verbs, then perhaps the auxiliary verb is better analyzed as a suffix on the main verb; perhaps the location of the negative markers can serve as a diagnostic for auxiliary verbs vs. suffixes. I leave this issue for future research.

The person/gender/number suffixes for each of the tenses and aspects described above (affirmative and negative) are summarized below in Table 1. It was observed above that the $1 \mathrm{sg}$ and $3 \mathrm{sgm}$ suffixes are always identical, as are the $2 \mathrm{sg}$ and $3 \mathrm{sgf}$ suffixes (except in the case of the imperative, since there is no $3 \mathrm{sgf}$ imperative form). Some further observations can be made about the form of the suffixes as follows. First, second person and feminine both appear to be marked with $t$. All second person and feminine suffixes begin with / $t$ / except for the Immediate Future and Future Potential; in those tenses/aspects, the second person and feminine suffixes contain $/ \mathrm{s} /$, which could be the reflex of a historical ${ }^{*} t$ (though the Central Somali correspondent to LJM Immediate Future also has /s/ in these suffixes (Saeed 1982: 24)).

A second generalization is that where $2 \mathrm{sg} / 3 \mathrm{sgf}$ has $/ \mathrm{t} / \mathrm{or} / \mathrm{s} /$, the $1 \mathrm{pl}$ suffix has $/ \mathrm{n} /$. This is the only difference between $2 \mathrm{sg} / 3 \mathrm{sgf}$ and $1 \mathrm{pl}$ in every tense/aspect except the Future Potential, in which there is also a vowel length difference between the suffixes -aso and -aano. In addition, the $2 \mathrm{pl}$ and $3 \mathrm{pl}$ suffixes are always identical except that $2 \mathrm{pl}$ has $/ \mathrm{t} /$ or $/ \mathrm{s} /$ where $3 \mathrm{pl}$ has $\varnothing$ or $/ \mathrm{y} /$; their vowels are always the same, though the vowel portion of these suffixes cannot be analyzed straightforwardly as constituting the plural marking, since as mentioned above, the $1 \mathrm{pl}$ suffixes pattern with the singular suffixes in terms of their vowels and overall shape. Interestingly, despite several vowel differences, these generaliza- 
tions about suffix consonants and suffix shapes in LJM are true of Central Somali (Saeed 1982) as well.

Table 1: Person/Number/Gender suffixes

Tense/Aspect

Simple Past/

Aff. $\quad-\mathrm{i} \quad-\mathrm{ti} \quad-n \mathrm{i} \quad$-teena $\quad$-eena

Past Progressive

Person/Number/Gender suffix on main verb

$$
1 \mathrm{sg} / 3 \mathrm{sgm} 2 \mathrm{sg} / 3 \mathrm{sgf} \quad \mathrm{lpl} \quad 2 \mathrm{pl} \quad 3 \mathrm{pl}
$$

Simp

Simple Present A/

Present Progressive

Neg. No person/number/gender suffix

Simple Present B

$\begin{array}{llllll}\text { Aff. } & - \text { ya } & \text {-ta } & \text {-na } & \text {-tena } & \text {-yena } \\ \text { Neg. } & - \text { yo } & \text {-to } & \text {-no } & \text {-tona } & \text {-yona }\end{array}$

Generic Future

\begin{tabular}{|c|c|c|c|c|}
\hline Aff. & $-y a$ & -te & - ne & -teena \\
\hline Neg. & -yo & -to & - no & -toona \\
\hline
\end{tabular}

Immediate Future

$\begin{array}{llllll}\text { Aff. } & \text {-e } & \text {-ase } & \text {-ane } & \text {-aseena } & \text {-ayeena } \\ \text { Neg. } & \text {-aw } & \text {-aso } & \text {-ano } & \text {-asoona }\end{array}$

Near Future/

Aff./

$-0 \quad-$ to

-no -tona -ona

Generic Potential Neg.

Imperative
Aff.
NA
$-\varnothing / \mathrm{NA}$
NA -a
NA
Neg
$\mathrm{NA} \quad-$ to/NA
$\mathrm{NA}$-tona NA

Future Potential

Aff./

-aw -aso

-aano -aasona

-aayona

Neg.

Past Habitual

Aff./ No person/number/gender suffix

Neg. 


\section{Conclusion.}

This paper has presented an overview of the phonology and morphology of Lower Jubba Maay. This is a previously undescribed language that is significantly different from dialects of Somali and Maay that have been described in the literature. It has been demonstrated that there are several areas of theoretical and typological interest in this language, in particular with regard to plural and gender marking in the nominal morphology.

\section{REFERENCES}

Andrzejewski, Bogumil. 1960. "The categories of number in noun forms in the Borana dialect of Galla". Africa 30: 62-75.

Armstrong, Lilias E. 1934. The Phonetic Structure of Somali. 1964 reprinted edition. Ridgewood, New Jersey: Gregg Press Incorporated.

Hyman, Larry M. 1981. "Tonal accent in Somali". Studies in African Linguistics 12.2: 169-201.

Kenstowicz, Michael. 1994. Phonology in Generative Grammar. Oxford: Blackwell.

Lecarme, Jacqueline. 2002. “Gender 'polarity': Theoretical aspects of Somali nominal morphology". Many Morphologies, ed. by Paul Boucher \& Marc Plénat. Somerville, Massachusetts: Cascadilla Press. Pp. 109-141.

Luling, Virginia. 1987. Somali-English Dictionary. Wheaton, Maryland: Dunwoody Press. 
Oomen, Antoinette. 1981. "Gender and plurality in Rendille”. Afroasiatic Linguistics 8.1: 35-75.

Saeed, John I. 1982. Central Somali: A Grammatical Outline. Monographic Journals of the Near East: Afroasiatic Linguistics 8.2. Malibu, California: Undena Publications.

Saeed, John I. 1987. Somali Reference Grammar. Wheaton, Maryland: Dunwoody Press.

Saeed, John I. 1999. Somali. Amsterdam/Philadelphia: John Benjamins Publishing Company.

Department of Linguistics and Cognitive Science

110 Mason Hall

[received May 22, 2006

550 North Harvard Avenue

accepted Sept. 2, 2006]

Pomona College

Claremont, CA 91711

mary.paster@pomona.edu 